\title{
The human cuneate nucleus contains discrete subregions whose neurochemical features match those of the relay nuclei for nociceptive information
}

\author{
Marina Del Fiacco • Marina Quartu • \\ Maria Pina Serra • Marianna Boi · Roberto Demontis • \\ Laura Poddighe $\cdot$ Cristina Picci $\cdot$ Tiziana Melis
}

Received: 12 February 2013/Accepted: 4 August 2013/Published online: 23 August 2013

(C) The Author(s) 2013. This article is published with open access at Springerlink.com

\begin{abstract}
The present paper is aimed at defining distinctive subdivisions of the human cuneate nucleus $(\mathrm{Cu})$, evident from prenatal to old life, whose occurrence has never been clearly formalized in the human brain, or described in other species so far. It extends our early observations on the presence of gray matter areas that host strong substance $\mathrm{P}$ (SP) immunoreactivity in the territory of the human $\mathrm{Cu}$ and adjacent cuneate fascicle. Here we provide a three-dimensional reconstruction of the $\mathrm{Cu}$ fields rich in SP and further identify those areas by means of their immunoreactivity to the neuropeptides SP, calcitonin gene-related peptide, methionine- and leucine-enkephalin, peptide histidine-isoleucine, somatostatin and galanin, to the trophins glial cell line-derived neurotrophic factor and brain-derived neurotrophic factor, and to the neuroplasticity proteins polysialylated neural cell adhesion molecule and growth-associated protein-43. The presence, density and distribution of immunoreactivity for each of these molecules closely resemble those occurring in the superficial layers of the caudal spinal trigeminal nucleus (Sp5C). Myelin and Nissl stainings suggest that those $\mathrm{Cu}$ subregions and the $\mathrm{Sp} 5 \mathrm{C}$ superficial layers share a similar histological aspect. This
\end{abstract}

The authors M. Del Fiacco, M. Quartu and M. P. Serra have equally contributed to the work.

M. Del Fiacco $(\bowtie) \cdot$ M. Quartu - M. P. Serra · M. Boi ·

L. Poddighe $\cdot$ C. Picci - T. Melis

Department of Biomedical Sciences, Section of

Cytomorphology, University of Cagliari, Cittadella

Universitaria, 09042 Monserrato, Italy

e-mail:dfiacco@unica.it

R. Demontis

Department of Public Health, Clinical and Molecular Medicine,

Azienda Ospedaliero Universitaria, University of Cagliari,

09042 Monserrato, Italy work establishes the existence of definite subregions, localized within the $\mathrm{Cu}$ territory, that bear the neurochemical and histological features of sensory nuclei committed to the neurotransmission of protopathic stimuli, including pain. These findings appear of particular interest when considering that functional, preclinical and clinical studies show that the dorsal column nuclei, classical relay station of fine somatic tactile and proprioceptive sensory stimuli, are also involved in pain neurotransmission.

Keywords Nucleus cuneatus - Dorsal column nuclei . Immunohistochemistry · Human medulla oblongata . Somatosensory neurotransmission $\cdot$ Pain

\section{Introduction}

The dorsal column-medial lemniscus system has classically been viewed as a pathway involved in conveying somatic epicritic tactile and kinesthetic sensory information to the thalamus. Several synaptic neurotransmitters have been identified in the dorsal column nuclei. Glutamate (Galindo et al. 1967; Roberts 1974; De Biasi and Rustioni 1990; De Biasi et al. 1994) and glycine and GABA (Galindo et al.1967; Roberts 1974; Rustioni et al. 1984; Westman 1989b; Heino and Westman 1991; Popratiloff et al. 1996; Lue et al. 2001) are, respectively, considered the primary excitatory and inhibitory neurotransmitters, whereas ATP (Galindo et al. 1967), acetylcholine (Henderson and Sherriff 1991), monoamines (Blomqvist and Broman 1993; Maqbool et al. 1993), and various neuropeptides (Vincent et al. 1985; Taber-Pierce et al. 1985; Westman 1989a; Tamatani et al. 1989; Conti et al. 1990; Fabri and Conti 1990) may also intervene as transmitters and/or modulators. As a general rule, the chemical neuroanatomy of 
second-order nuclei that relay protopathic sensibility, including nociceptive input, namely the spinal dorsal horn, the caudal part of the spinal trigeminal nucleus (Sp5C) and the solitary nucleus, differs from that of the dorsal column nuclei. This is particularly evident for a number of neuropeptides. Thus, for instance, compared to dorsal column nuclei, protopathic sensory nuclei host greater amounts of nerve fibers and terminals (and, for some neuropeptides, perikarya) immunoreactive to substance $\mathrm{P}$ (SP) (Cuello and Kanazawa 1978; Ljungdahl et al. 1978; Del Fiacco et al. 1984), calcitonin gene-related peptide (CGRP) (Skofitsch and Jacobowitz 1985b; Unger and Lange 1991; van Rossum et al. 1997), methionine- (M-EK) and leucineenkephalin (L-EK) (Simantov et al. 1977; Haber and Elde 1982; Conrath-Verrier et al. 1983), somatostatin (SOM) (Johansson et al. 1984; Taber-Pierce et al. 1985; Vincent et al. 1985; Chigr et al. 1989), and galanin (GAL) (Skofitsch and Jacobowitz 1985a; Melander et al. 1986; Kordower et al. 1992). Second-order sensory nuclei for protopathic and epicritic sensation differ in a similar way in their content of other neuroactive substances, such as the trophins brain-derived neurotrophic factor (BDNF) (Tang et al. 2010; Yan et al. 1997) and glial cell-derived neurotrophic factor (GDNF) (Jongen et al. 1999; Quartu et al. 1999; Kawamoto et al. 2000; Del Fiacco et al. 2002), and markers of neuronal plasticity, such as the highly polysialylated neural cell adhesion molecule (PSA-NCAM) (Bonfanti et al. 1992; Seki and Arai 1993; Quartu et al. 2008) and the growth-associated protein-43 (GAP-43) (Benowitz et al. 1988; Wiese et al. 1991; Nacimiento et al.1993; Del Fiacco et al. 1994; Jain et al. 1995; Quartu et al. 1995; Zou and Martin 1995). On the other hand, early studies in our laboratory (Del Fiacco et al. 1983, 1984) showed that the human cuneate nucleus $(\mathrm{Cu})$ and adjacent fascicle contain discrete gray matter subregions that host a very rich plexus of nerve fibers and terminals strongly immunoreactive to SP, a neuropeptide that, while showing a neuroregulatory action on a variety of functions, appears definitely involved in pain transmission (Hökfelt et al. 1977; Pearson et al. 1982; De Koninck et al. 1992). This peculiar localization was detectable in specimens from subjects at age ranging from prenatal life to old age (Del Fiacco et al. 1983, 1984) and has been subsequently confirmed in the human infant (Rikard-Bell et al. 1990). It also appeared as a distinctive feature of the human medulla oblongata, which has never been reported in other species,
Table 1 List of specimens

$F$ female, $d$ days, $h$ hours, $M$ male, $y$ years, w.g. weeks of gestation (calculated from the 1 st day of the latest menstrual cycle)

\begin{tabular}{|c|c|c|c|c|}
\hline Case & Age & Sex & Primary cause of death & Post-mortem (h) \\
\hline 1 & Fetus 21 w.g. & $\mathrm{F}$ & Cardiorespiratory failure & 29 \\
\hline 2 & Fetus 38 w.g. & M & Gestosis & 38 \\
\hline 3 & Pre-term newborn $6 \mathrm{~d}$ ( 25 w.g.) & $\mathrm{F}$ & Pneumonitis & 25 \\
\hline 4 & Pre-term newborn 4 d (34 w.g.) & M & Pneumonitis & 32 \\
\hline 5 & Pre-term newborn $1 \mathrm{~d}$ (34 w.g.) & M & Cardiorespiratory failure & 29 \\
\hline 6 & Pre-term newborn (38 w.g.) & M & Cardiorespiratory failure & 38 \\
\hline 7 & Full-term newborn (40 w.g.) & M & Cardiorespiratory failure & 28 \\
\hline 8 & Full-term newborn $17 \mathrm{~h}$ & $\mathrm{~F}$ & Patency of Botallo's duct & 26 \\
\hline 9 & Full-term newborn $1 \mathrm{~d}$ & M & Cardiorespiratory failure & 24 \\
\hline 10 & Full-term newborn $2 \mathrm{~d}$ & $\mathrm{~F}$ & Persistence of fetal circulation & 38 \\
\hline 11 & Full-term newborn $55 \mathrm{~h}$ & M & Cardiorespiratory failure & 30 \\
\hline 12 & Full-term newborn $7 \mathrm{~d}$ & $\mathrm{~F}$ & Cardiorespiratory failure & 27 \\
\hline 13 & Adult $32 \mathrm{y}$ & M & Hypertrophic cardiomyopathy & 24 \\
\hline 14 & Adult $42 \mathrm{y}$ & M & Cardiorespiratory failure & 49 \\
\hline 15 & Adult $44 \mathrm{y}$ & M & Stabbing & 40 \\
\hline 16 & Adult $46 \mathrm{y}$ & M & Pneumonitis & 31 \\
\hline 17 & Adult 48 y & $\mathrm{F}$ & Myocardial infarction & 24 \\
\hline 18 & Adult 53 y & $\mathrm{F}$ & Cardiorespiratory failure & 31 \\
\hline 19 & Adult $53 \mathrm{y}$ & $\mathrm{F}$ & Pneumonitis & 28 \\
\hline 20 & Adult $56 \mathrm{y}$ & $\mathrm{F}$ & Cardiomyopathy & 34 \\
\hline 21 & Adult 71 y & M & Renal failure & 25 \\
\hline 22 & Adult 72 y & $\mathrm{F}$ & Acute pulmonary edema & 27 \\
\hline 23 & Adult $77 \mathrm{y}$ & $\mathrm{F}$ & Myocardial infarction & 26 \\
\hline 24 & Adult $88 \mathrm{y}$ & $\mathrm{M}$ & Thromboembolysm of pulmonary artery & 47 \\
\hline
\end{tabular}


so far. Our later studies showed that immunoreactivity to other molecules, namely GAP-43 (Quartu et al. 1995), GDNF family ligands (Del Fiacco et al. 2002; Quartu et al. 2007b), and their cognate receptors (Quartu et al. 2007a), also labels distinctively some restricted subregions within the territory of the $\mathrm{Cu}$ and cuneate fascicle. Here we present further data showing the position and extent of the strongly SP-immunoreactive fields within the Cu territory of the human newborn medulla oblongata and provide evidence that, in newborn and adult tissue, the same discrete gray matter subregions host immunoreactivity to several other neuropeptides, neurotrophins GDNF and BDNF, and neuroplasticity proteins PSA-NCAM and GAP-43, with distribution pattern and density that strictly match those of the Sp5C; finally, the localization of those subregions in the adult medulla oblongata is illustrated by reference to the relevant diagrams of the human brainstem nuclei from Paxinos et al. (2012). The main goal of the present paper is to definitely determine the existence of such peculiar subdivisions of the human $\mathrm{Cu}$, constantly detectable from developmental age to old life, and add information regarding their position and neurochemical properties.

\section{Materials and methods}

Specimens of medulla oblongata were obtained at autopsy from subjects with no signs of neuropathology, at age ranging 21 gestation weeks to 88 years (Table 1). The sampling and handling of human specimens conformed to the local Ethics Committee of the National Health System in compliance with the principles enunciated in the Declaration of Helsinki. Fixation in $4 \%$ freshly prepared phosphate-buffered formaldehyde, $\mathrm{pH} 7.3$, for $4-6 \mathrm{~h}$ at $4{ }^{\circ} \mathrm{C}$, was followed by overnight rinsing in $0.1 \mathrm{M}$ phosphate buffer (PB), pH 7.3, containing 5-20\% sucrose. Transverse sections of the medulla oblongata were cut with a cryostat at $10-14$ or $30 \mu \mathrm{m}$ and collected in series of adjacent slices on chrome alum-gelatin coated slides. The indirect immunofluorescence (Coons and Kaplan 1950) in single and double staining, and the avidin-biotin-peroxidase complex (ABC) immunostaining techniques were applied using primary antibodies against neuropeptides SP, CGRP, M-EK, L-EK, peptide histidine-isoleucine (PHI), SOM and GAL, trophins GDNF and BDNF, and neuroplasticity marker molecules GAP-43 and PSA-NCAM. Details on primary and secondary antibodies and staining

Table 2 Primary and secondary antibodies used

\begin{tabular}{|c|c|c|c|}
\hline & Source & Dilution & Incubation \\
\hline \multicolumn{4}{|l|}{ Primary antibody } \\
\hline Rat monoclonal anti-SP & $\begin{array}{l}\text { Cuello et al. (1979); Sera Lab, } \\
\text { NCL } 5220064\end{array}$ & $1: 300$ & $\begin{array}{l}1 \mathrm{~h} \text { at room temperature } \\
\text { or overnight at } 4{ }^{\circ} \mathrm{C}\end{array}$ \\
\hline Rabbit polyclonal anti-SP & CRB, CA-08-335 & $1: 1,200$ & Overnight at $4{ }^{\circ} \mathrm{C}$ \\
\hline Rabbit polyclonal anti-CGRP & Peninsula Labs, RAS-6009-N & $1: 300$ & $\begin{array}{l}1 \mathrm{~h} \text { at room temperature } \\
\text { or overnight at } 4{ }^{\circ} \mathrm{C}\end{array}$ \\
\hline Rabbit polyclonal anti-M-EK & Probert et al. (1983) & $1: 300$ & Overnight at $4{ }^{\circ} \mathrm{C}$ \\
\hline Rabbit polyclonal anti-L-EK & Wharton et al. (1980) & $1: 300$ & Overnight at $4{ }^{\circ} \mathrm{C}$ \\
\hline Rabbit polyclonal anti-PHI & Bishop et al. (1984); CRB, CA-08-310 & $1: 200$ & Overnight at $4{ }^{\circ} \mathrm{C}$ \\
\hline Rabbit polyclonal anti-SOM & Incstar Corp., 20088 & $1: 200$ & Overnight at $4{ }^{\circ} \mathrm{C}$ \\
\hline Rabbit polyclonal anti-GAL & CRB, CA-08-250 & $1: 1,000$ & Overnight at $4{ }^{\circ} \mathrm{C}$ \\
\hline Rabbit polyclonal anti-GDNF & SantaCruz Biotechnology & $1: 400$ & Overnight at $4{ }^{\circ} \mathrm{C}$ \\
\hline Rabbit polyclonal anti-BDNF & SantaCruz Biotechnology & $1: 400$ & Overnight at $4{ }^{\circ} \mathrm{C}$ \\
\hline Mouse monoclonal anti-PSA-NCAM & Chemicon & $1: 400$ & Overnight at $4{ }^{\circ} \mathrm{C}$ \\
\hline Mouse monoclonal anti-GAP-43 & Schreyer and Skene (1991) & $1: 1,000$ & Overnight at $4{ }^{\circ} \mathrm{C}$ \\
\hline \multicolumn{4}{|l|}{ Secondary antibody } \\
\hline DTAF-conjugated goat anti-rat serum & Jackson & $1: 50$ & $40-60 \mathrm{~min}$ at room temperature \\
\hline TRITC-conjugated goat anti-rat serum & Jackson & $1: 50$ & $40-60 \mathrm{~min}$ at room temperature \\
\hline FITC-conjugated sheep anti-rabbit serum & Wellcome & $1: 40$ & $40-60 \mathrm{~min}$ at room temperature \\
\hline DTAF-conjugated goat anti-rabbit serum & Jackson & $1: 100$ & $40-60 \mathrm{~min}$ at room temperature \\
\hline TRITC-conjugated goat anti- rabbit serum & Jackson & $1: 100$ & $40-60 \mathrm{~min}$ at room temperature \\
\hline Biotin-conjugated goat anti-mouse serum & Jackson & $1: 50$ & $60 \mathrm{~min}$ at room temperature \\
\hline Biotin-conjugated goat anti-rabbit serum & Jackson & $1: 100$ & $60 \mathrm{~min}$ at room temperature \\
\hline Biotin-conjugated goat anti-rabbit serum & Vector & $1: 200$ & $60 \mathrm{~min}$ at room temperature \\
\hline
\end{tabular}



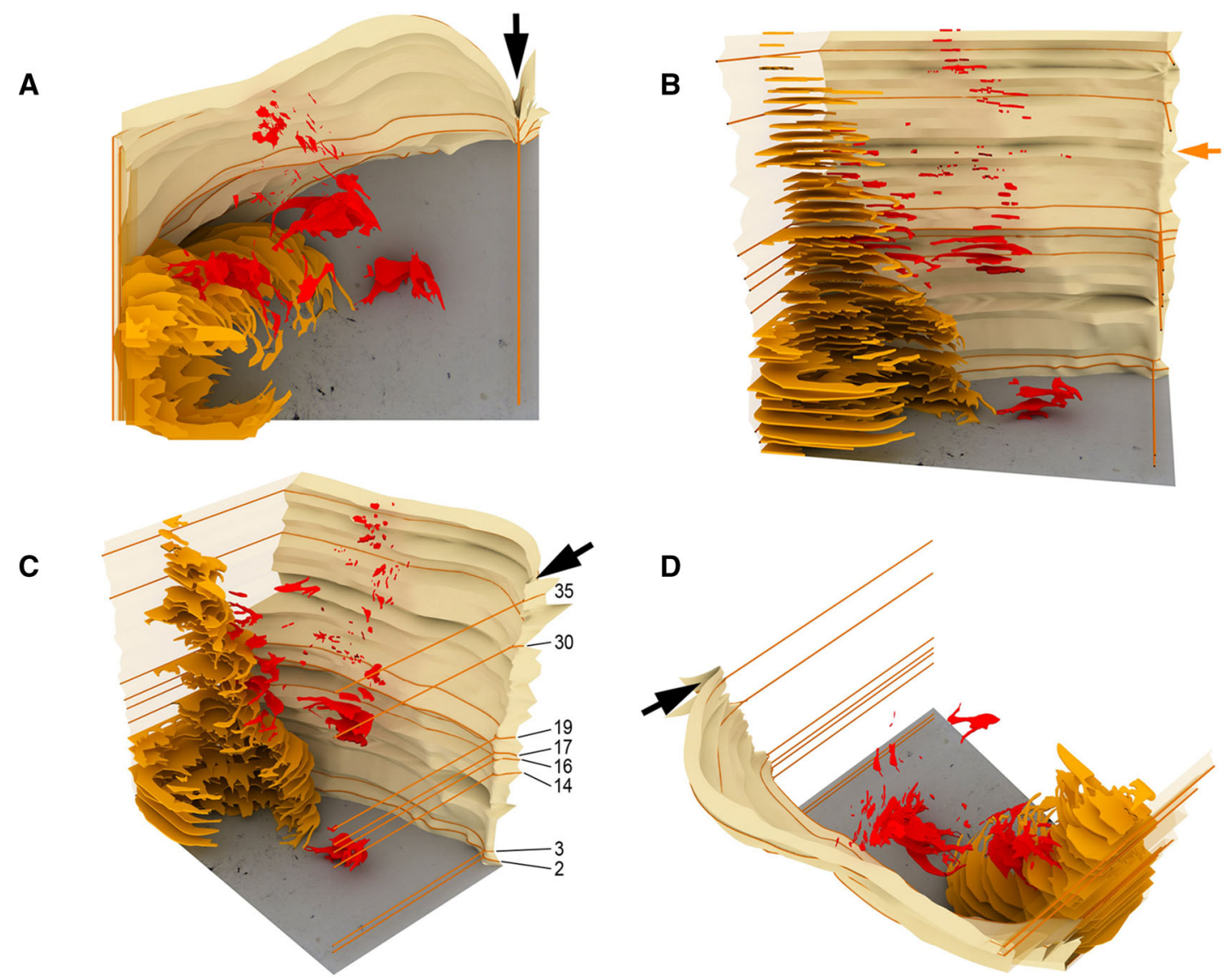

\section{E 2}

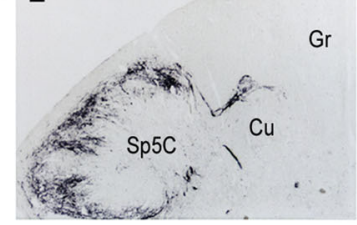

14

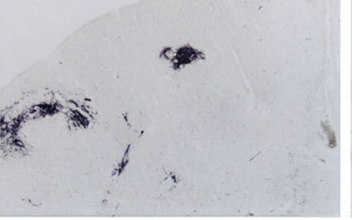

17

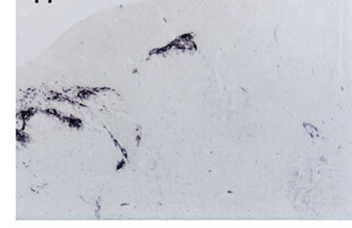

30

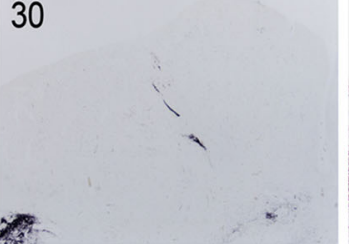

$2 a$

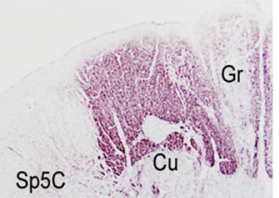

Sp5C

$4 a$
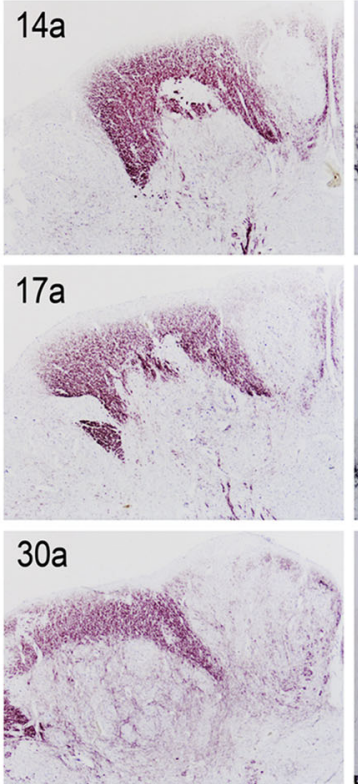

3

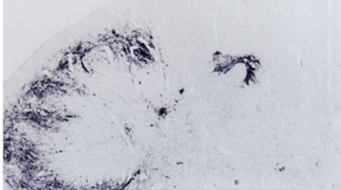

16

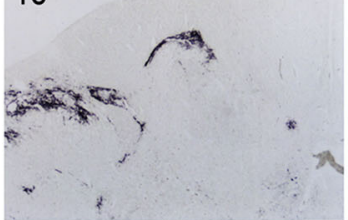

19

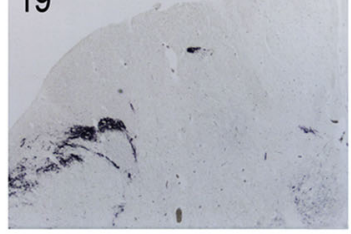

35

$\therefore$
$3 a$

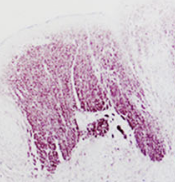

$16 a$

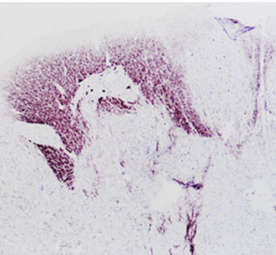

$19 a$

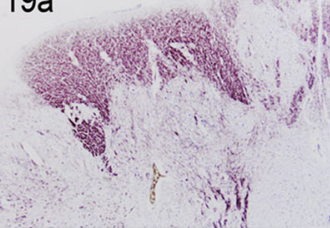

$35 a$

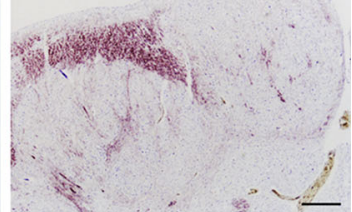


4Fig. 1 Full-term newborn, case 9. A-D 3D rendering of SPimmunoreactive areas in the territory of the cuneate nucleus and fascicle (red) and in the substantia gelatinosa of the spinal trigeminal nucleus, caudal part (yellow) as seen in thirty-seven $12 \mu \mathrm{m}$ thick serial sections of the medulla oblongata left dorsal quadrant. Sections are distant $120 \mu \mathrm{m}$ from one another, for a total thickness of about $4.5 \mathrm{~mm}$; the top level is about $740 \mu \mathrm{m}$ caudal to the obex. Arrows in $\mathbf{A}, \mathbf{C}, \mathbf{D}$ and $\mathbf{E} 2$ point to the posterior median sulcus and septum; the midsagittal plane was used to align the section images. Views from the top (A), anterior (B), anteromedial-superior (C), dorsolateralsuperior (D). Levels of sections 2, 3, 14, 16, 17, 19, 30, and 35 in caudo-rostral sequence are indicated by orange lines and are numbered in $\mathbf{C}$. Corresponding sections and paired, $36 \mu \mathrm{m}$ distant, sections stained for myelin are shown in $\mathbf{E}$. Orange arrow in $\mathbf{B}$ indicates the level of the caudal pole of the external cuneate nucleus. E $C u$ cuneate nucleus, $G r$ gracile nucleus, $S p 5 C$ spinal trigeminal nucleus, caudal part. Scale bar in $\mathbf{E} 35 a=500 \mu \mathrm{m}$ applies to all micrographs

protocols are listed in Table 2. In ABC stainings, the immunoreaction was revealed with $30 \mathrm{~min}$ incubation in ABC (BioSpa Div.), diluted 1:250, followed by incubation with a solution of $0.1 \mathrm{M} \mathrm{PB}, \mathrm{pH} 7.3$, containing $0.05 \%$ 3-3'-diaminobenzidine (Sigma), $0.04 \%$ nickel ammonium sulfate, and $0.01 \%$ hydrogen peroxide. All antisera and
$\mathrm{ABC}$ were diluted in phosphate-buffered saline (PBS) containing $0.2 \%$ Triton X-100. Double-labeling immunofluorescence for SP and a second peptide was attained with the rat monoclonal antibody against SP and a second primary antibody raised in rabbit either by incubating the sections in a mixture of the primary antibodies followed by a mixture of the appropriate secondary antisera, or by performing sequentially two single immunoreactions for SP and one of the other neuropeptides. Negative control preparations were obtained either by incubating tissue sections with diluted primary antibody that had been preabsorbed with $10 \mathrm{mM}$ of the respective peptide for $24 \mathrm{~h}$ at $4{ }^{\circ} \mathrm{C}$, with preabsorption of the anti-PSA-NCAM antibody with $5 \mathrm{mg}$ of colominic acid (alfa-2-8-linked sialic polymer colominic acid), or by omitting the primary antibody. In double immunolabeling, cross preabsorption of each primary antibody with the other peptide did not alter the staining pattern. Cresyl violet, Black-Gold II staining kit (Biosensis) and Kluver-Barrera method were used as Nissl and myelin stainings. Slides stained by immunofluorescence were mounted in glycerol/PBS 3:1 (V/V); slides

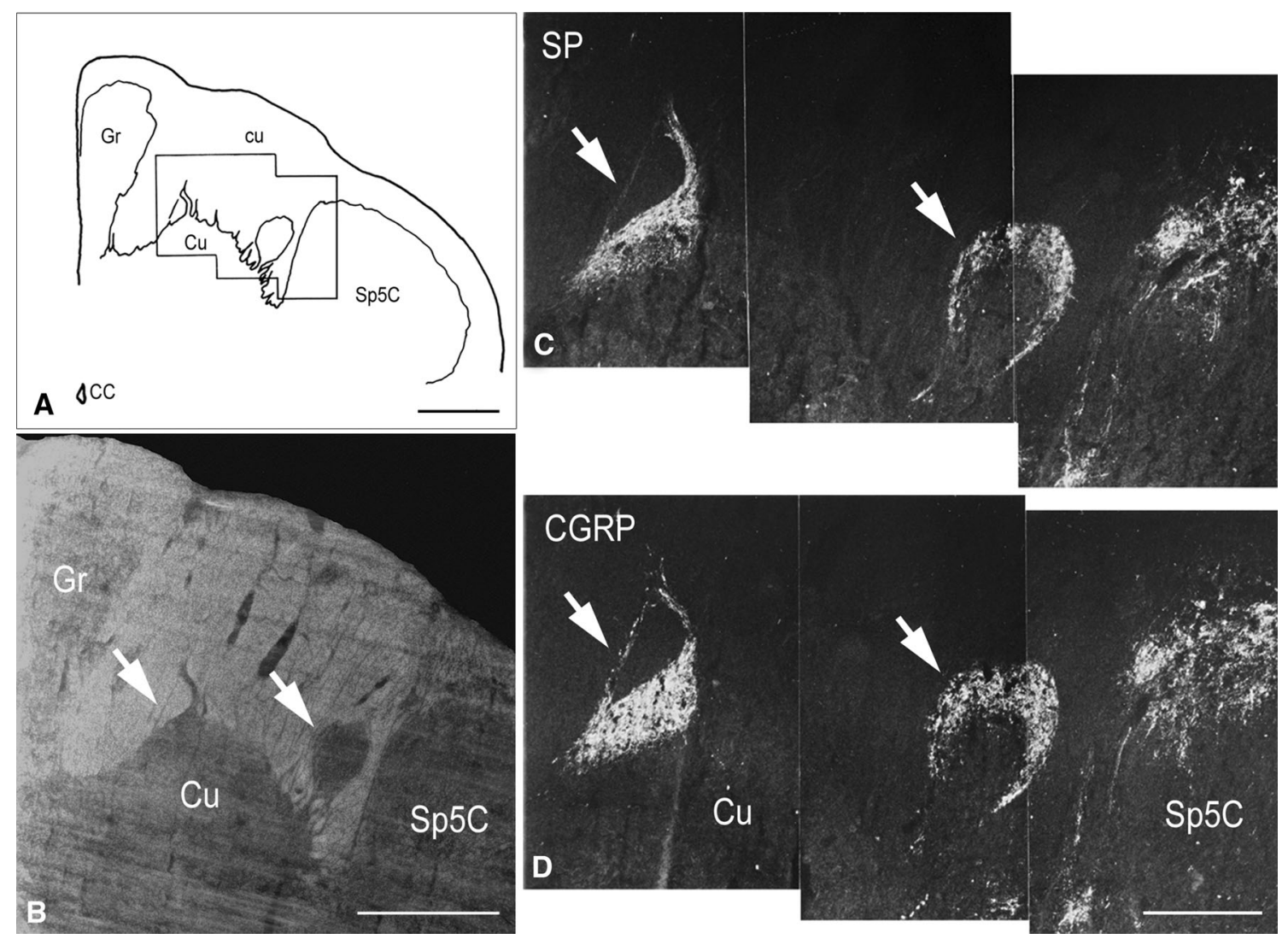

Fig. 2 Full-term newborn, case 11. A Schematic drawing of the dorsal right quadrant of the caudal medulla oblongata transverse section shown in $\mathbf{B}$ and $\mathbf{C}$; the black frame indicates the field shown in C and D. B Bright field orientation image of the territory of the cuneate nucleus $(\mathrm{Cu})$ in a section immunostained for SP (detail in $\mathbf{C}$ ). C, D Two adjacent sections immunostained for SP and CGRP, respectively, showing the dorsal part of the caudal $\mathrm{Cu}$ and the dorsomedial part of the spinal trigeminal nucleus, caudal part (Sp5C). Arrows in $\mathbf{B}-\mathbf{D}$ indicate the immunoreactive $\mathrm{Cu}$ regions. $C C$ central canal, $c u$ cuneate fascicle, $G r$ gracile nucleus. Scale bars A, $\mathbf{B}=1 \mathrm{~mm}, \mathbf{C}=\mathbf{D}=500 \mu \mathrm{m}$ 


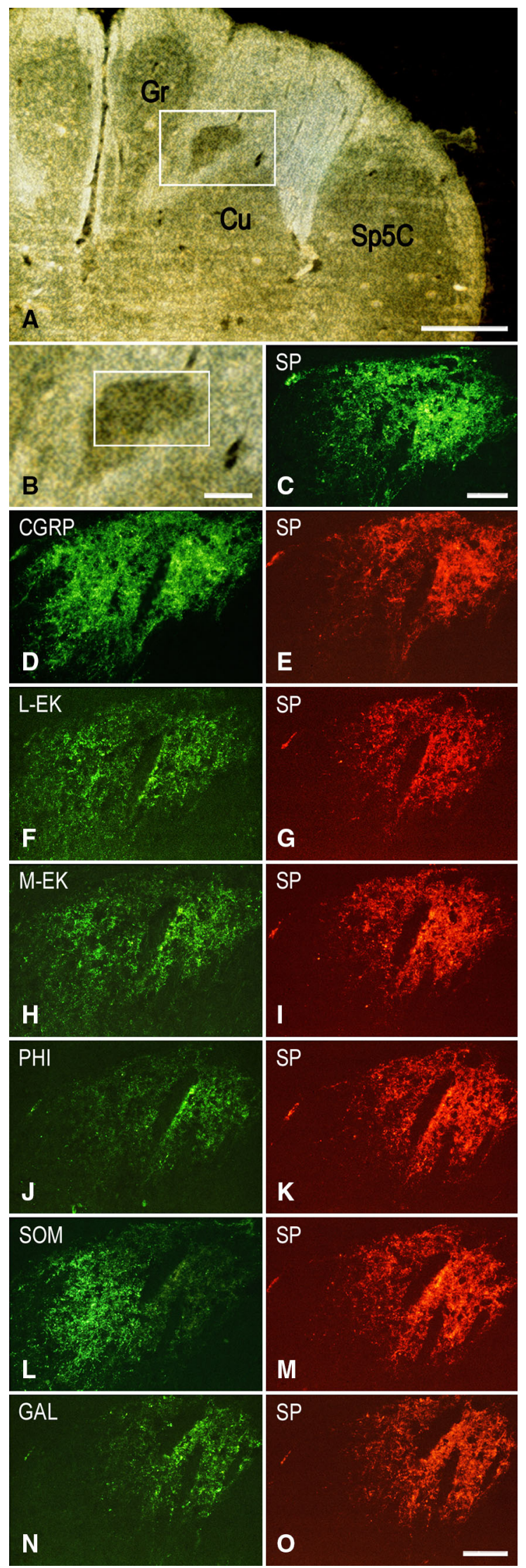

\Fig. 3 Full-term newborn, case 8. Series of seven consecutive sections of caudal medulla oblongata immunostained for SP (A, B, C) and double immunostained for CGRP (D), L-EK (F), M-EK (H), PHI (J), SOM (L), GAL (H) (DTAF fluorochrome), and SP (E, G, I, $\mathbf{K}, \mathbf{M}, \mathbf{O}$, respectively) (TRITC fluorochrome). Images $\mathbf{A}, \mathbf{B}$ and $\mathbf{C}$ belong to the same section immunostained for SP. A Bright field orientation image of the right dorsal quadrant: white box delineates the area shown in $\mathbf{B}$ at higher magnification. $\mathbf{B}$ Region of gray matter dorsomedial to the main cuneate nucleus $(\mathrm{Cu})$; white box delineates the area shown in C. C Dark field image of the SP immunoreactivity. $\mathbf{D}, \mathbf{E}$ to $\mathbf{N}, \mathbf{O}$ Dark field paired micrographs of the area shown in $\mathbf{C}$ in six consecutive double immunostained sections. $G r$ gracile nucleus, Sp5C spinal trigeminal nucleus, caudal part. Scale bars $\mathbf{A}=1 \mathrm{~mm}$, $\mathbf{B}=250 \mu \mathrm{m}, \mathbf{C}=100 \mu \mathrm{m}, \mathbf{D}-\mathbf{N}=\mathbf{O}=100 \mu \mathrm{m}$

stained by $\mathrm{ABC}$ immunoperoxidase, cresyl violet, BlackGold II kit and/or Kluver-Barrera technique were dehydrated and coverslipped. Observations and photographs were made with epifluorescence equipped photomicroscopes Leitz Dialux 20 and Olympus BX61, and with Nanozoomer 2.0-RS (Hamamatsu). Using the photographs of a series of 37 consecutive sections of medulla oblongata dorsal quadrant, the three-dimensional rendering of the SPimmunoreactive areas present in the $\mathrm{Cu}$ of a full-term newborn was obtained by the software Rhinoceros 5.0 (Robert McNeel \& Associates). Diagrams of appropriate levels of the human medulla oblongata nuclei from Paxinos et al. (2012), reduced to the dorsal quadrant and simplified by removing lettering of non-pertinent structures, have been paired to CGRP-immunostained sections of adult medulla oblongata to show the localization of the identified subregions in the adult.

\section{Results}

In the caudal human medulla oblongata of all examined specimens, from fetal and young postnatal age (Figs. 1, 2, 3, 4, 5) to adult life (Figs. 6, 7, 8, 9), at levels between the pyramidal decussation and the obex, the territory of the cuneate fascicle and nucleus contains distinct areas of gray matter that differ from the remaining dorsal column nuclear complex with respect to their immunoreactivity to the examined substances. Networks of varicose filaments and dot-like structures, interpreted as nerve fibers and terminals, are revealed in them by immunostaining for the neuropeptides, GDNF, PSA-NCAM, and GAP-43; in addition, immunoreactivity to PSA-NCAM also shows profiles of cell bodies and proximal processes, suggestive of perikarya membrane labeling. Nerve fibers and terminals compose plexuses of variable density for the different markers, from very thick (SP, CGRP) to rather dense plexuses (SOM, M- and L-EK, GDNF, PSA-NCAM, GAP43 ), or networks of moderate density (GAL, PHI). In these 
areas, no immunolabeling occurs for BDNF. By contrast, the remaining territory of the main $\mathrm{Cu}$ hosts scarce varicose fibers immunoreactive to the neuropeptides and GDNF, a thin mesh of filaments stained for GAP-43, rare filaments and profiles of cell bodies stained for PSA-NCAM, and strongly labeled neuronal perikarya, fibers and terminals for BDNF. The following description will focus on the localization pattern of the examined substances in the areas of strong SP immunoreactivity, whereas that in the main $\mathrm{Cu}$ will not be further described. No immunostaining was detectable in control preparations. However, as we can not completely exclude the possibility of non-specific adhesion of primary antibodies to unknown tissue components, the labeling should be correctly considered as "substance-like immunoreactivity".

Compared to the outcome in newborn tissue, density of immunoreactive structures slightly lessens in adult specimens; immunoreactivity to GAP-43 and PSA-NCAM, while decreasing substantially in several gray and white matter areas, yet persisted in these regions with no major age changes. No gender differences were observed.

The position and shape of the $\mathrm{Cu}$ gray matter subregions that are strongly immunoreactive to SP, as detected in 37 consecutive sections encompassing about $4.5 \mathrm{~mm}$ caudorostral extent of a full-term newborn specimen, is illustrated in three-dimensional rendering in Fig. 1A-D. The largest extent of the SP-immunoreactive fields occurs below the level of the external cuneate nucleus caudal pole (indicated in Fig. 1B) and concentrates in two distinct caudo-rostral segments, separated by an interval of about $1 \mathrm{~mm}$. At higher levels, where pars rotunda and pars triangularis of the main $\mathrm{Cu}$ are present, the immunoreactivity is localized to very small areas within the dorsomedial cuneate fascicle and at the boundary with the gracile territory (Fig. 1E 19-35a), where it has the aspect of thin bundles of fibers; it is undetectable at levels rostral to the obex. Alternate sections stained for myelin show the topographical localization of the immunoreactive subregions (Fig. 1E). Depending on the level considered, the immunoreactivity is placed in the superficial part of a somewhat larger gray matter area. Such a distribution may be clearly appreciated in Figs. 1E 2-2a and 16-16a, 2A-C, $3 \mathrm{~A}-\mathrm{C}$. Otherwise, the two territories almost coincide (Fig. 5A, B). Also, they may appear as part of the dorsal contour of the $\mathrm{Cu}$, more or less protruding dorsally (Figs. 2C, 4A, $\mathrm{A}_{1}, 5 \mathrm{D}, \mathrm{E}, 7 \mathrm{~A}$ ), or within islands of gray matter entirely embedded in the cuneate fascicle (Figs. 3C, 5B). Two distinct SP-positive zones may appear in the horizontal plane, one located medially and the other one laterally along the dorsal boundary of the $\mathrm{Cu}$ (Figs. 2C, 6A, 7A). Although their position may be close to the neighboring nuclei, topographically they are clearly related to the $\mathrm{Cu}$ rather than to the gracile and spinal trigeminal nuclei. The medially located region may show a triangular or oval profile, whereas the lateral one is round-shaped. In both areas, immunoreactivity to SP is located along the periphery and, in the lateral one, is contained in a crescentshaped superficial layer (Figs. 2C, 6A, 7A). The thick plexus of nerve fibers and terminals is alike that present in the adjacent substantia gelatinosa of the Sp5C (Figs. 2C, 7A). At appropriate levels, it may be seen that shoots of immunoreactive varicose fibers from the white matter immediately dorsal to the Sp5C substantia gelatinosa join the laterally located area (Fig. 1E 2) and that the medial and lateral fields are connected by a bridge of gray matter that contains immunoreactive fibers (Fig. 6A, C). At some levels, a single area of immunostained gray matter occurs dorsomedial or dorsal to the main $\mathrm{Cu}$; it is roughly triangular in shape and grows oval and transversely elongated at more rostral levels (Figs. 1E 14-16a, 3A-C, 4A, A 1 , 5A, B).

sections shows that the $\mathrm{Cu}$ subregions with strong immunoreactivity to SP contain rare myelinated fibers (Fig. 5F, $\mathrm{F}_{1}$ ). In a similar way, the SP-immunoreactive substantia gelatinosa of the Sp5C (Fig. 5D) contains sparse stained fibers (Fig. 5F, $\mathrm{F}_{3}$ ), whereas numerous myelinated fibers can be seen running across the territory of the main $\mathrm{Cu}$ (Fig. 5F, $\mathrm{F}_{2}$ ). Nissl staining of adult tissue (Fig. 6) indicates that in the dorsal $\mathrm{Cu}$ subregions the cells may be smaller and more closely packed than in the main $\mathrm{Cu}$ (Fig. 6C- $\mathrm{C}_{2}$ ), their histological aspect appearing rather similar to that of the Sp5C substantia gelatinosa (Fig. $6 \mathrm{C}_{2}$, $\mathrm{C}_{3}$ ).

Together with SP, immunoreactivity to CGRP, L- and M-EK, PHI, SOM, GAL occurs in these regions with distinctive distribution and density for each of them (Figs. 2, 3, 4A, $\left.\mathrm{A}_{1}, \mathrm{~B}, \mathrm{~B}_{1}, 5 \mathrm{~A}-\mathrm{C}, 7 \mathrm{~A}, \mathrm{~B}, 8 \mathrm{~B}\right)$. Double immunostaining for each peptide and SP in a series of adjacent sections (Fig. 3D-O) allows comparison of the localization pattern of neuropeptides with respect to one another. Structures immunoreactive for CGRP overlap those positive for SP, but are more abundant and reach more deeply into the area (Fig. 3D, E); immunoreactivity for L- and M-EK has a distribution similar to that for CGRP, but density of EK-positive elements is obviously lower compared to CGRP- (Fig. 3, compare F, H with D) and SPpositive ones (Fig. 3F-I); staining for $\mathrm{PHI}$ is distributed as that for SP, but is comparatively scarce (Fig. 3J, K); SOMpositive elements are located more deeply than those positive to SP and hardly overlap with them (Fig. 3L, M); immunoreactive material for GAL, though much less dense, overlaps that for SP (Fig. 3N, O). Figures 2, 4A-B , $5,7 \mathrm{~A}, \mathrm{~B}$ show that the codistribution of SP and CGRP in the $\mathrm{Cu}$ subregions parallels that present in the $\mathrm{Sp} 5 \mathrm{C}$ superficial layers, the immunostaining for CGRP being more intense than that for SP in both sites. With a similar 

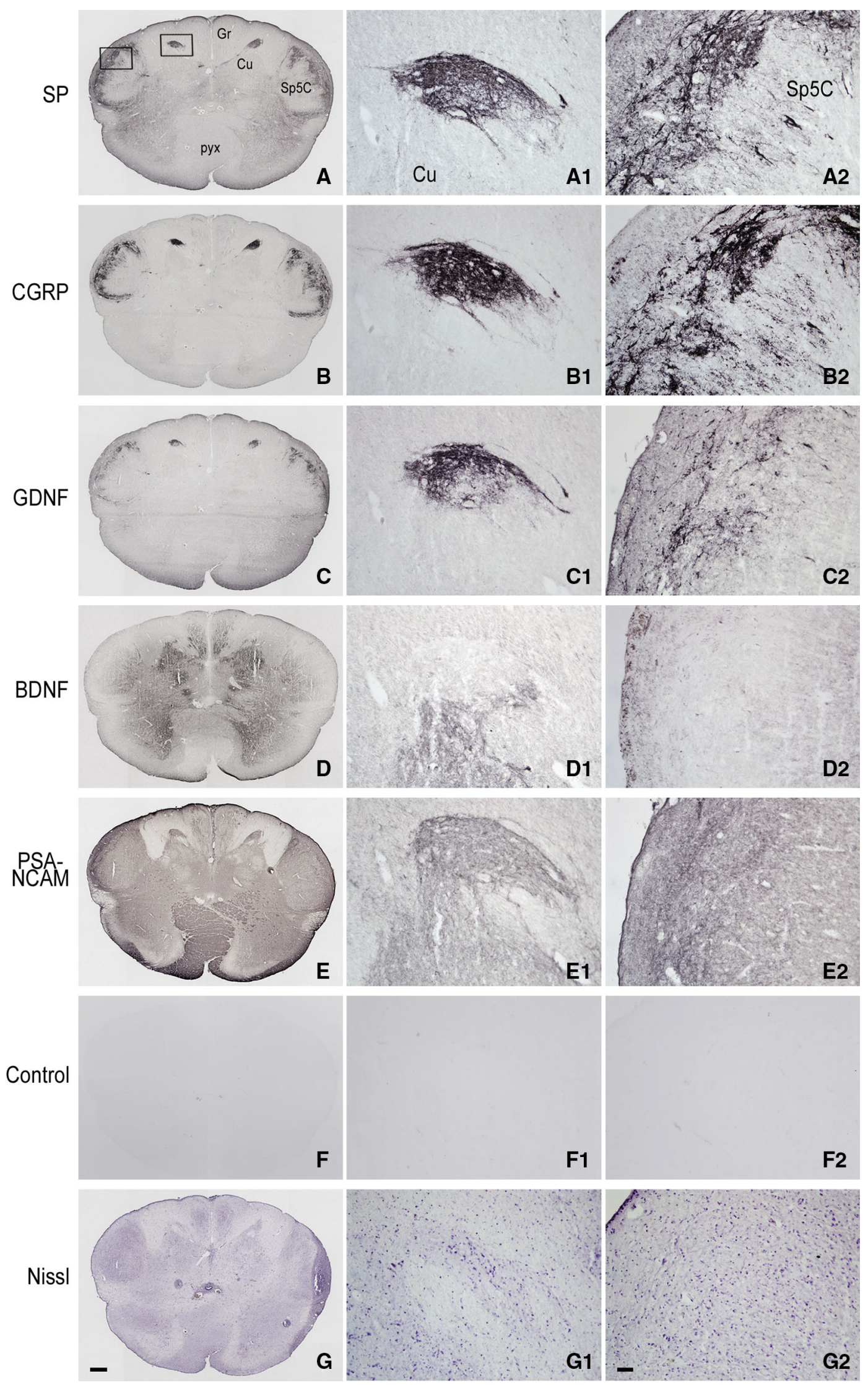
4 Fig. 4 Pre-term newborn, case 5. A-G Series of seven consecutive sections of caudal medulla oblongata immunostained for SP (A), CGRP (B), GDNF (C), BDNF (D), PSA-NCAM (E) and as control (preabsorbed anti-PSA-NCAM primary antibody; preabsorbed antibodies against the other molecules yielded a similar outcome), and Nissl stained with cresyl violet $(\mathbf{G})$. Boxes in $\mathbf{A}$ delineate the areas shown in $\mathbf{A}_{\mathbf{1}}-\mathbf{G}_{\mathbf{1}}$ and $\mathbf{A}_{\mathbf{2}}-\mathbf{G}_{\mathbf{2}}$. $\mathbf{A}_{\mathbf{1}}-\mathbf{G}_{\mathbf{1}}$ Higher magnification of the dorsal gray matter area in the left side cuneate nucleus $(\mathrm{Cu})$ detectable in $\mathbf{A}-\mathbf{G}$ sections, respectively. $\mathbf{A}_{\mathbf{2}}-\mathbf{G}_{\mathbf{2}}$ Detail at higher magnification of the left side substantia gelatinosa of the spinal trigeminal nucleus, caudal part (Sp5C), detectable in A-G sections, respectively. $\mathrm{Gr}$ gracile nucleus, pyx pyramidal decussation. Scale bars $\mathbf{A}-$ $\mathbf{F}=\mathbf{G}=500 \mu \mathrm{m}, \mathbf{A}_{\mathbf{1}}-\mathbf{G}_{\mathbf{1}}$ and $\mathbf{A}_{\mathbf{2}}-\mathbf{F}_{\mathbf{2}}=\mathbf{G}_{\mathbf{2}}=50 \mu \mathrm{m}$

strict correspondence in aspect, localization and density of immunoreactive structures detectable in the Sp5C superficial layers, the $\mathrm{Cu}$ subregions are also immunoreactive to GDNF (Fig. 4C- $\mathrm{C}_{2}$ ), PSA-NCAM (Fig. 4E-E $\mathrm{E}_{2}$ ) and GAP43 (Figs. 7C, 8B), and not to BDNF (Figs. $4 \mathrm{D}-\mathrm{D}_{2}, 8 \mathrm{C}$ ). The aspect and position of the gray matter subregions in the adult medulla oblongata, as they appear in CGRP-immunostained and Kluver-Barrera counterstained tissue sections, are illustrated in Fig. 9 at some representative levels in caudo-rostral sequence. As reference, matching level diagrams, modified from Paxinos et al. (2012), are drawn aside. At caudalmost levels (Fig. 9A), below the $\mathrm{Cu}$ caudal pole, two immunoreactive small areas occur medial to the dorsomedial Sp5C substantia gelatinosa and immediately ventral to the cuneate fascicle. They have a different rostrocaudal extent, and only one of them or both, as in Fig. 9A, may appear in the same section. Moving rostrally, a single small area appears, more medially located and entirely embedded within the ventromedial cuneate fascicle; it enlarges rostrad and the immunoreactivity occupies its dorsolateral part (Fig. 9B, C). This area, both for its position and localization of immunoreactive material, is very similar to the one shown in newborn tissue in Figs. 3 and 4. Further rostrally and for at least $2 \mathrm{~mm}$, it is not present (Fig. 9D). Laterally, a round-shaped region appears, which contains the immunoreactive elements in a semilunar superficial part. This region is very similar to that detected in newborn tissue and shown in Fig. 2. Rostrad, it grows larger and seems to split in two portions (Fig. 9D), which, at a higher level, diverge further, the medial one approching the dorsal border of the $\mathrm{Cu}$ (Fig. 9E). At the same point, a gray matter immunoreactive area appears again dorsal to the main $\mathrm{Cu}$ (Fig. 9E), roughly aligned with the one present at lower levels. It does not extend much rostrally and is not present at $\mathrm{Cu}$ middle level, when pars rotunda and pars triangularis are visible (Fig. 9F). Shoots of immunoreactive fibers bridge the ventrolateral cuneate fascicle, connecting the dorsalmost territory of the trigeminal spinal tract to the lateral border of $\mathrm{Cu}$ (Fig. 9F). At this and higher levels up to the obex, the gray matter immunoreactivity dies down, whereas thin fiber bundles appear in the dorsomedial cuneate fascicle, as shown in the newborn tissue in Fig. 1E 30, 35. Alternate sections immunostained for SP and counterstained with cresyl violet show a similar distribution for the peptide (not shown).

\section{Discussion}

The data presented confirm our previous reports on the occurrence of gray matter areas that contain a rich plexiform network of intense SP immunoreactivity in the territory of the human $\mathrm{Cu}$ and cuneate fascicle, located at levels spanning from the pyramidal decussation to the obex and detectable throughout life, from fetal to adult age (Del Fiacco et al. 1983, 1984). These areas begin to appear at the level of the caudal reticular pole of the main $\mathrm{Cu}$ and continue rostrally, placed along the dorsal border of the main $\mathrm{Cu}$. At their larger extent, they appear located at two separated caudo-rostral levels, both below the level of the external $\mathrm{Cu}$ caudal pole. At middle level of the main $\mathrm{Cu}$, when pars rotunda and pars triangularis are present, they grow small and the immunoreactivity is restricted to spotlike regions embedded in the dorsomedial cuneate fascicle. Detailed descriptions of the human dorsal column nuclei in Nissl and acetylcholinesterase (AChE) stained transverse sections have been provided in recent years (Paxinos et al. 1990; Paxinos and Huang 1995; Koutcherov et al. 2004). The possibility that some intensely AChE reactive regions within the territory of the $\mathrm{Cu}$ and cuneate fascicle correspond to those we described earlier as strongly immunoreactive to SP has been put forward (Paxinos et al. 1990, 2012; Koutcherov et al. 2004). Comparison of the present data with the most recent diagrammatic representation of the human brainstem by Paxinos et al. (2012) suggests that the islands of gray matter indicated by those authors as trigeminal substantia gelatinosa (abbreviated as $\mathrm{Sp5C}$ ) within the ventral cuneate fascicle may correspond to the small immunoreactive regions occurring medial to the dorsomedial end of the $\mathrm{Sp} 5 \mathrm{C}$ substantia gelatinosa at levels immediately caudal to the $\mathrm{Cu}$ caudal pole. By contrast, the immunoreactive area that starts to appear at the $\mathrm{Cu}$ caudal pole is definitely more medially situated than the regions seen below and the $\mathrm{Sp5C} 2$ drawn in diagrams. Moreover, CGRP immunoreactivity occupies only its dorsolateral part, suggesting that the whole area may correspond to a territory wider than a mere substantia gelatinosa. Further rostrally, the immunoreactive gray matter subregions present in the caudal $\mathrm{Cu}$ are not identified and drawn as specific territories in those diagrams. We detected clusters of few large cells well stained with Nissl in the cuneate fascicle, which correspond well to the very small islands of external $\mathrm{Cu}$ drawn by Paxinos et al. (2012). However, 

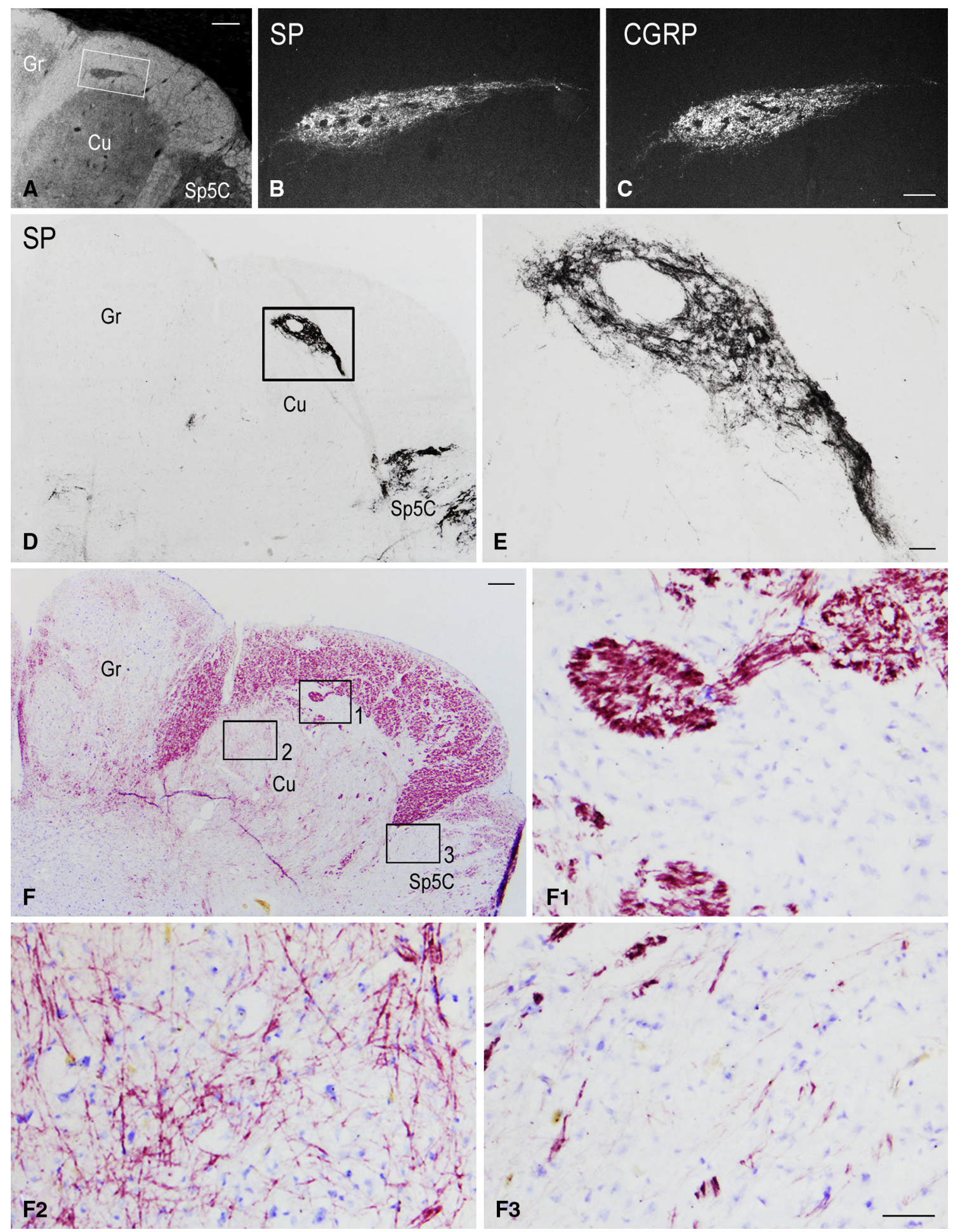

Fig. 5 Full-term newborn, case $11(\mathbf{A}-\mathbf{C})$ and $9\left(\mathbf{D}-\mathbf{F}_{\mathbf{3}}\right)$. A Bright field orientation image of the territory of the right cuneate nucleus $(\mathrm{Cu})$ in a section of caudal medulla oblongata immunostained for SP (detail in darkfield in B): white box indicates area shown at higher magnification in B. B, C Two adjacent sections immunostained for SP and CGRP, respectively, showing the immunoreactive region of gray matter dorsal to the main $\mathrm{Cu}$. D Right dorsal quadrant of a section immunostained for SP; the strongly immunoreactive area present

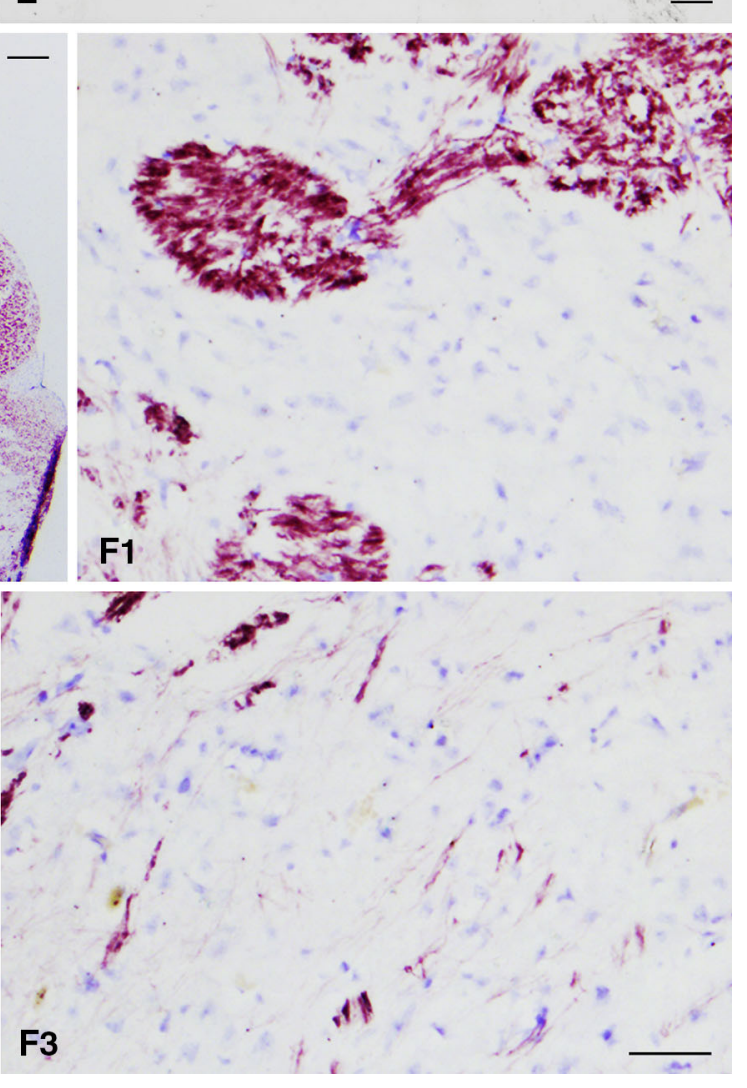

along the dorsal border of the $\mathrm{Cu}$ (box) is shown at higher magnification in E. F Right dorsal quadrant of a section consecutive to D stained for myelin and Nissl; boxes 1, 2 and 3 outline fields of the SP-immunoreactive $\mathrm{Cu}$ subregion, main $\mathrm{Cu}$ and caudal spinal trigeminal nucleus (Sp5C) substantia gelatinosa, respectively, shown at higher magnification in $\mathbf{F}_{\mathbf{1}}-\mathbf{F}_{\mathbf{3}}$. Gr gracile nucleus. Scale bars $\mathbf{A}=500 \mu \mathrm{m}, \mathbf{B}=\mathbf{C}=100 \mu \mathrm{m}, \mathbf{D}=\mathbf{F}=250 \mu \mathrm{m}, \mathbf{E}=50 \mu \mathrm{m}, \mathbf{F}_{\mathbf{1}}$, $\mathbf{F}_{\mathbf{2}}=\mathbf{F}_{\mathbf{3}}=250 \mu \mathrm{m}$ 

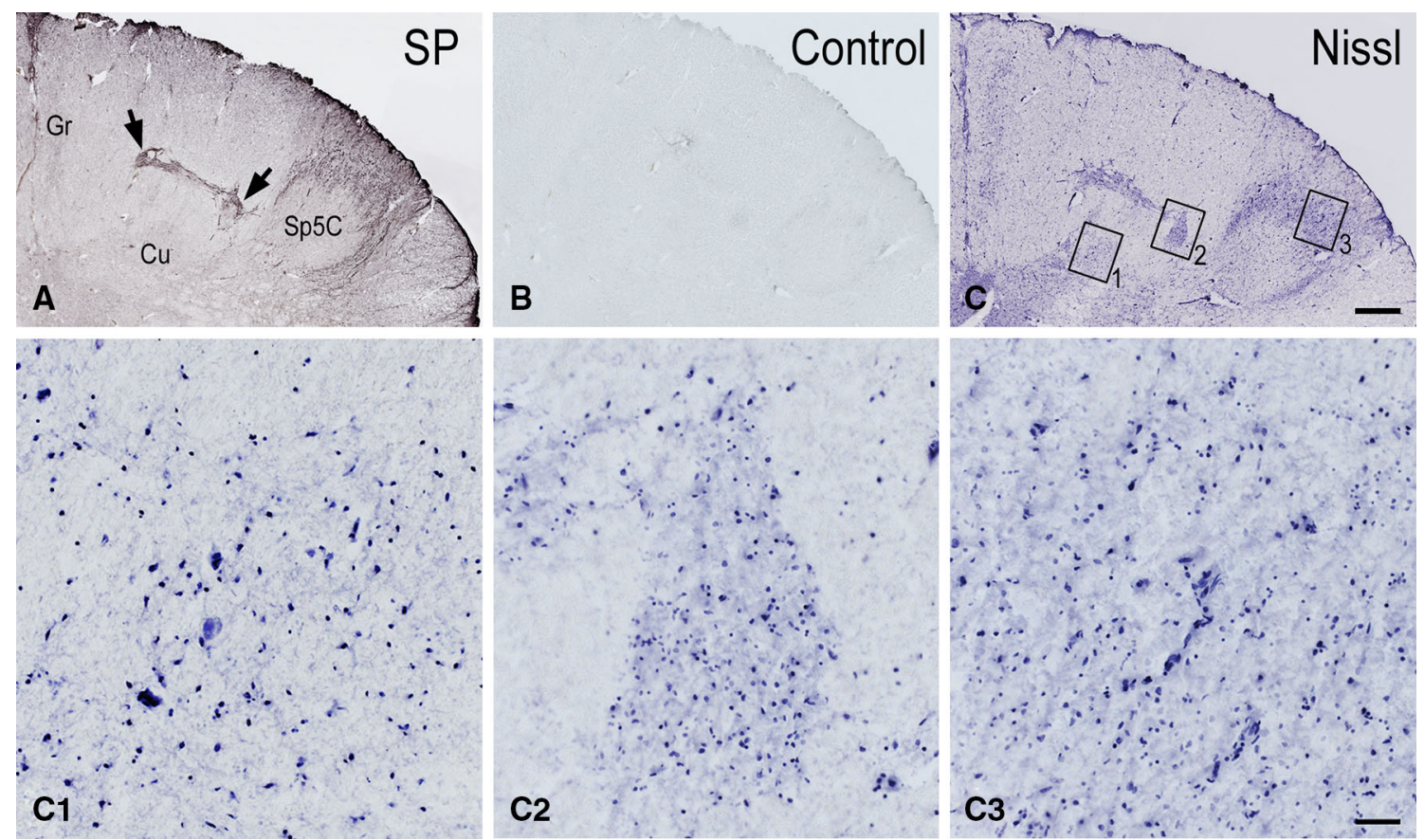

Fig. 6 Adult, case 18. A-C Right dorsal quadrant of three consecutive sections of caudal medulla oblongata immunostained for SP (A) and as control (preabsorbed anti-SP primary antibody) (B), and Nissl stained $(\mathbf{C})$. Details at higher magnifications of the Nissl stained main cuneate nucleus $(\mathrm{Cu})$ (box 1 in $\mathbf{C}$ ), a region of the $\mathrm{Cu}$ territory immunoreactive to SP (box 2 in $\mathbf{C}$, compare to $\mathbf{A}$ ), and the caudal

contrary to the speculation by Paxinos et al. (2012) that they may correspond to the SP-positive regions we described earlier, their neuropil is not immunoreactive to SP or CGRP and, conversely, the regions identified by their immunoreactivity to the examined substances host small neurons.

Thus, the regions described here appear distinct from the known subdivisions of the dorsal column nuclear complex present at their same level, including the medial pericuneate nucleus, which is ventral to the dorsal column nuclei, and the lateral pericuneate nucleus, which is ventral and lateral to the external $\mathrm{Cu}$ (Paxinos et al. 1990, 2012). Even more obviously, they are distinct from the nuclei of the complex located above the obex level, such as the paratrigeminal nucleus and nucleus $\mathrm{X}$. The present work further shows that immunoreactivity to neuropeptides CGRP, Land M-EK, GAL, SOM and PHI, plasticity proteins PSANCAM and GAP-43, and trophin GDNF, but not BDNF, also occurs in these regions and that the aspect, distribution pattern and density of immunostained elements for all these molecules match up strictly with those detected in the Sp5C. Such a strict resemblance may be further appreciated by comparing the present data with our previous descriptions of the Sp5C immunoreactivity to the examined neuropeptides (Del Fiacco and Quartu 1994; Quartu et al. 1992; Quartu and Del Fiacco 1994), GAP-43 (Del Fiacco spinal trigeminal nucleus (Sp5C) substantia gelatinosa (box 3 in C) are shown in $\mathbf{C}_{\mathbf{1}}-\mathbf{C}_{\mathbf{3}}$, respectively. Arrows in A point to two SPimmunostained regions connected by a bridge of immunoreactive gray matter. $G r$ gracile nucleus. Scale bars $\mathbf{A}, \mathbf{B}=\mathbf{C}=500 \mu \mathrm{m} ; \mathbf{C}_{\mathbf{1}}$, $\mathbf{C}_{2}=\mathbf{C}_{3}=50 \mu \mathrm{m}$

et al. 1994), GDNF (Del Fiacco et al. 2002) and PSANCAM (Quartu et al. 2008). Nissl and myelin stainings support the concept of a similar histological organization between the detected immunoreactive fields and the Sp5C substantia gelatinosa. We consider that the present observations provide a clear-cut indication for the existence of distinct subregions (which may possibly be considered as a single whole structure) in the human dorsal column nuclear complex, placed in the territory of the main $\mathrm{Cu}$ and cuneate fascicle, never formally determined so far and whose neurochemical anatomy bears a striking resemblance to that of the spinal and brainstem sensory nuclei committed to transmit protopathic stimuli, including pain. At various levels, they may appear composed of a deep part, almost devoid of immunoreactivity, and a superficial part where the immunoreactivity for the examined substances parallels that present in the superficial layers of the Sp5C (present data; Del Fiacco et al. 1984; Chigr et al. 1989; Rikard-Bell et al. 1990; Unger and Lange 1991; Quartu et al. 1992, 1999, 2008; Del Fiacco and Quartu 1994; Quartu and Del Fiacco 1994; Del Fiacco et al. 1994; 2002; Yan et al. 1997; Kawamoto et al. 2000) and spinal dorsal horn (Cuello et al. 1976; De Lanerolle and LaMotte 1982; Anand et al. 1984; Chung et al. 1989; Unger and Lange 1991; Nacimiento et al. 1993; Bonfanti et al. 1992; Jongen et al. 1999; Kawamoto et al. 2000; Del Fiacco et al. 2002; Schoenen and 

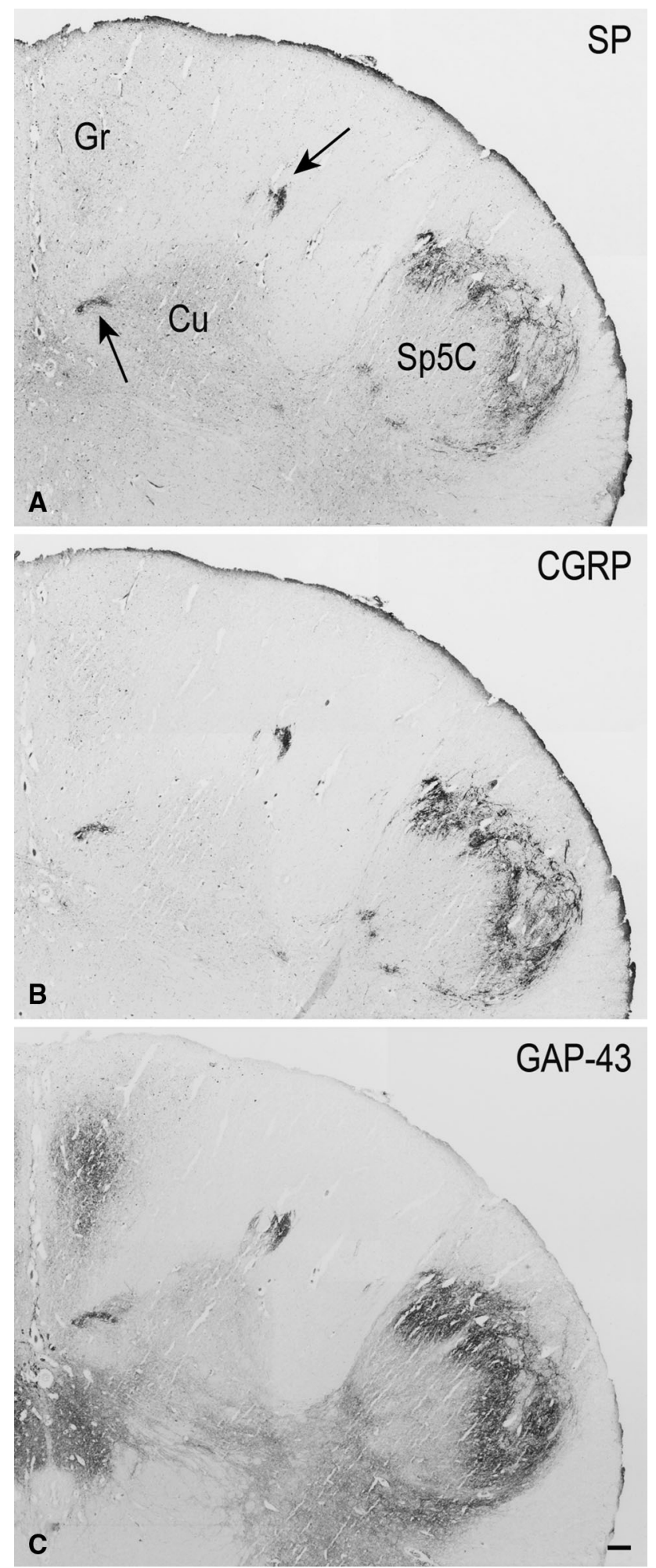

Fig. 7 Adult, case 19. A-C Right dorsal quadrant of three consecutive sections of caudal medulla oblongata immunostained for SP (A), CGRP (B) and GAP-43 (C). Immunoreactvity for the three molecules occurs in two regions of the cuneate nucleus $(\mathrm{Cu})$ (pointed out by arrows in $\mathbf{A}$ ), as in the superficial layers of the spinal trigeminal nucleus, caudal part (Sp5C). $G r$ gracile nucleus. Scale bar A, $\mathbf{B}=\mathbf{C}=250 \mu \mathrm{m}$
Faull 2004). Thus, the observed immunolocalizations suggest to explore the possibility that these subregions contain a superficial laminar pattern in their structural organization.

Vast amount of literature on the chemical anatomy of the somatosensory system in different animal species, including man, shows how immunoreactivity to the examined molecules, abundant in the superficial laminae of the spinal dorsal horn, $\mathrm{Sp} 5 \mathrm{C}$, and solitary nucleus, is generally scarce and dispersed throughout in the dorsal column nuclei (see references in Introduction; Rustioni and Weinberg 1989; Broman 1994). Several experimental studies report a significant intensification of the immunoreactivity to some neuropeptides in dorsal column nuclei after peripheral nerve damage (Hoeflinger et al. 1993; Zhang et al. 1993; Noguchi et al. 1995; Ma and Bisby 1997; Miki et al. 1998; Yeh et al. 2008) and in aging (Kitagawa et al. 2005); moreover, according to the welldocumented notion that GAP-43 synthesis and axonal transport raise in neurons responding to peripheral nerve injury (Skene 1984; Bisby 1988), increased levels of the protein were observed in monkey $\mathrm{Cu}$ after median nerve lesion and repair (Jain et al. 1995) and in rat gracile nucleus after sciatic nerve crush injury (Woolf et al. 1990). In this respect, it is to be underlined that our observations were made on normal specimens and that, as a rule, the immunoreactivity in specimens from aged subjects was less pronounced or less densely packed than in young tissue.

In agreement with their preferential localization to sensory nuclei that receive protopathic sensory signals, the examined neuropeptides (see above for references), GDNF (Holstege et al. 1998) and GAP-43 (Tetzlaff et al. 1989) are functionally related to the neurotransmission of protopathic sensibility, including pain, and are mostly contained there in unmyelinated or thinly myelinated primary afferent fibers and in local circuit neurons. Moreover, typically PSA-NCAM persists in adult tissue in the superficial laminae of the spinal dorsal horn (Bonfanti et al. 1992) and Sp5C (Quartu et al. 2008). Though, in the rat, BDNF may play a role as an anterograde trophic messenger in unmyelinated or thinly myelinated primary afferent fibers to spinal dorsal horn neurons (Michael et al. 1997), in our hands BDNF immunoreactivity is undetectable in the identified subregions of the human $\mathrm{Cu}$ as well as in the trigeminal substantia gelatinosa and the latter finding appears in agreement with what reported in the rat Sp5C by Yan et al. (1997).

By contrast, the possibility that some of the examined neuropeptides play a role in the sensory modalities traditionally ascribed to the dorsal column nuclei, namely fine somatic tactile and proprioceptive perception, may also be considered. In fact, CGRP-positive fibers have been shown to innervate the light touch mechanoreceptor Meissner's 


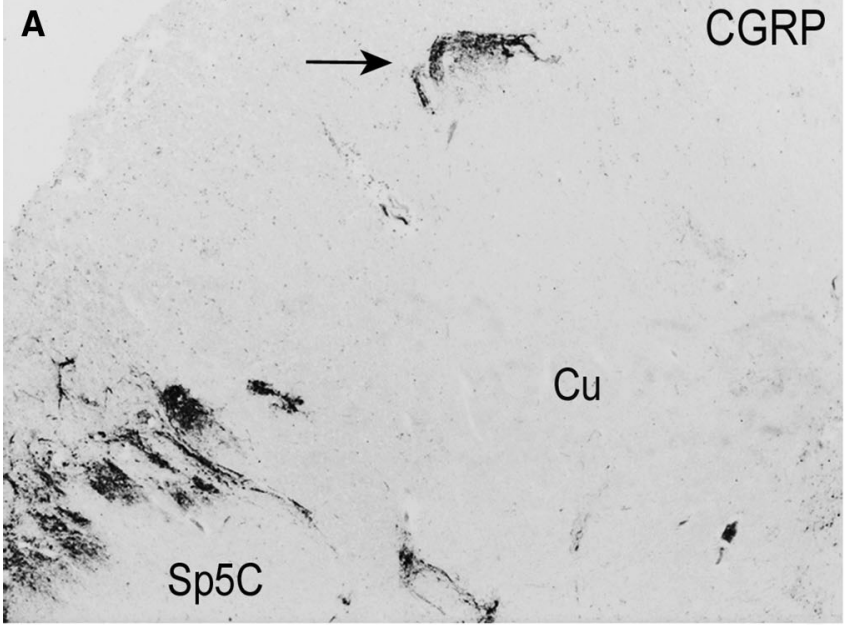

C

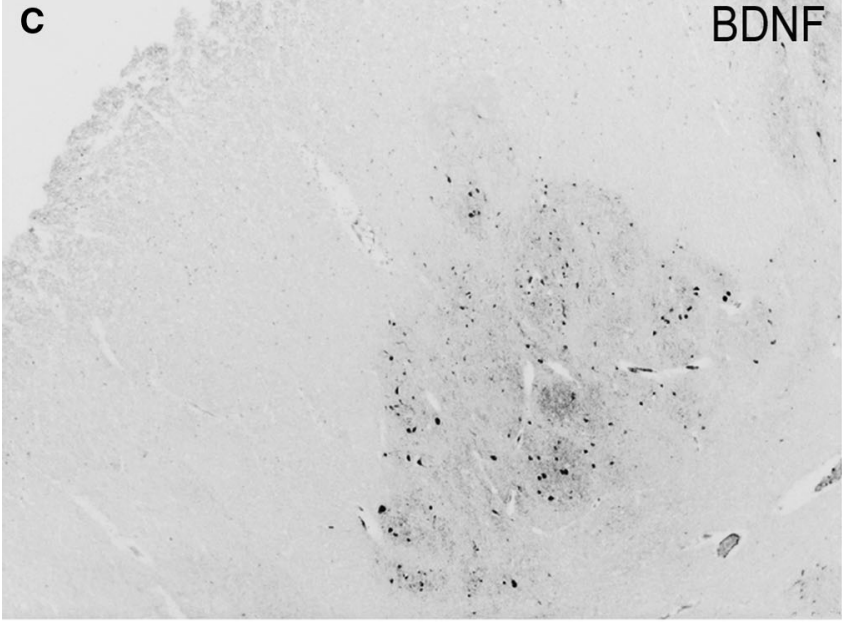

Fig. 8 Adult, case 14. A-D Left side cuneate nucleus $(\mathrm{Cu})$ and dorsomedial part of the caudal spinal trigeminal nucleus (Sp5C) substantia gelatinosa in four consecutive sections of caudal medulla oblongata immunostained for CGRP (A), GAP-43 (B), BDNF (C), and as Control (preabsorbed anti-BDNF primary antibody;

corpuscles (Ishida-Yamamoto et al. 1988), and SP-positive fibers also occur in human (Dalsgaard et al. 1983; our unpublished observation) and rat Meissner's corpuscles (Ishida-Yamamoto et al. 1988), and in other mechanoreceptors such as human Ruffini's and Pacini's corpuscles (Ide et al. 1996). Moreover, the possible involvement of SP in the neurotransmission of proprioceptive stimuli is suggested by its localization in the human nucleus dorsalis of Clarke (Pioro et al. 1984).

The dorsal column-medial lemniscus system has classically been viewed as a pathway devoted to transmission of fine touch, vibratory sense and proprioception, and the dorsal columns have been considered as composed mostly of thick myelinated primary sensory fibers. However, it is now well established that a substantial amount of the dorsal column fibers are thin and unmyelinated (Langford and Coggeshall 1981; Chung and Coggeshall 1985; Chung

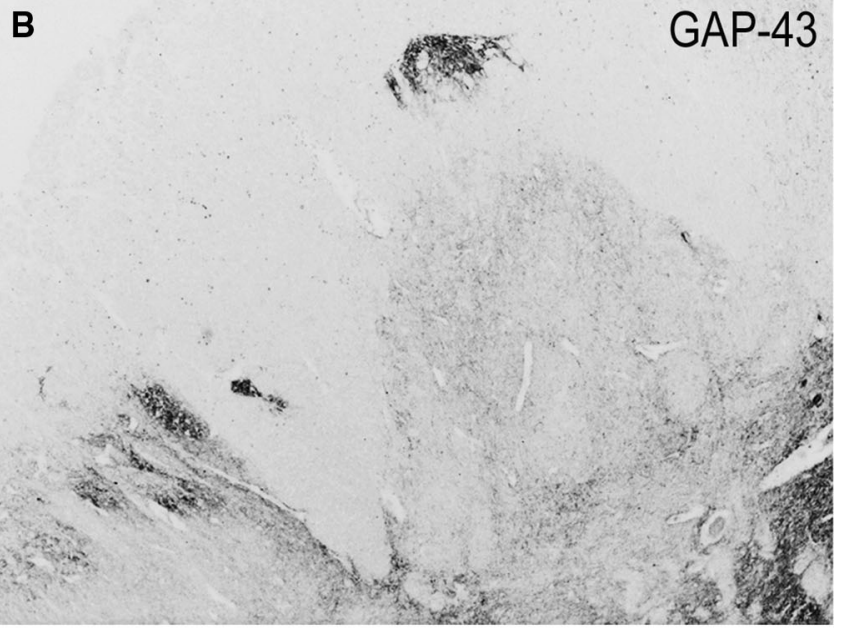

D

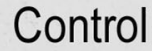

preabsorbed antibodies against the other molecules yielded a similar outcome). Note how the immunoreactivity of the dorsal region of the $\mathrm{Cu}$ (arrow in $\mathbf{A}$ ) goes in parallel to that of the substantia gelatinosa of the $\mathrm{Sp} 5 \mathrm{C}$ for the three molecules. Scale bar $\mathbf{A}-\mathbf{C}=\mathbf{D}=250 \mu \mathrm{m}$

et al. 1987), their proportion exceeding $25 \%$ in the human sacral spinal cord (Briner et al. 1988). In the rat, many of these fibers are of primary afferent origin and, among the latter, most are immunoreactive to CGRP (McNeill et al. 1988; Tamatani et al. 1989; Patterson et al. 1990) and a smaller number to SP (Tamatani et al. 1989). In human tissue, SP-immunoreactive fibers run longitudinally along the dorsal border of the cuneate fascicle and bend obliquely at its ventrolateral border, towards the adjacent $\mathrm{Cu}$ territory (Del Fiacco et al. 1984). These observations were confirmed in the present study; CGRP-positive fibers were also seen with similar position and orientation (not shown). The possibility of a primary sensory origin other than spinal ganglia is suggested by the presence of CGRP and SPimmunoreactive fibers extending from the territory of the dorsal spinal trigeminal tract to the ventrolateral cuneate fascicle and adjacent nucleus; such an observation is in 

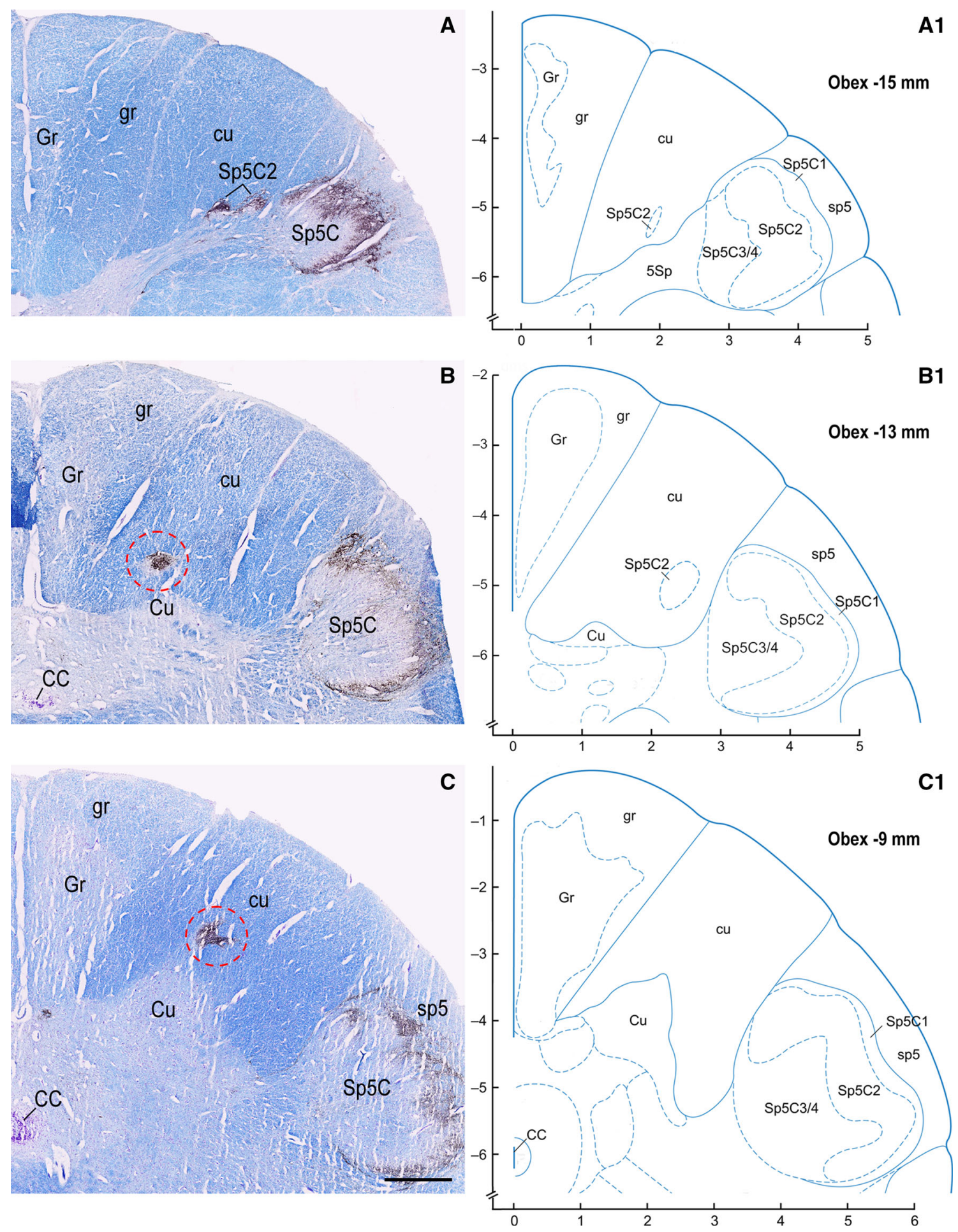

Fig. 9 Adult, case 15. A-F Right dorsal quadrant of caudal medulla oblongata sections immunostained for CGRP and counterstained with Kluver-Barrera. $\mathbf{A}_{\mathbf{1}}-\mathbf{F}_{\mathbf{1}}$ diagrams modified from Paxinos et al. (2012) at levels indicated as distance from obex, matching those shown in AF. Gray matter regions endowed with CGRP immunoreactivity and located medially $(\mathbf{B})$, dorsally $(\mathbf{C}, \mathbf{E})$ and laterally $(\mathbf{D}, \mathbf{E})$ in the cuneate fascicle $(\mathrm{cu})$ near the cuneate nucleus $(\mathrm{Cu})$ border are encircled in red. Note that similar regions do not appear in the

matching level diagrams. $C C$ central canal; $C u R$ cuneate nucleus, pars rotunda; $C u T$ cuneate nucleus, pars triangularis; $E C u$ external cuneate nucleus; $G r$ gracile nucleus; $g r$ gracile fasciculus; $s p 5$ spinal trigeminal tract; $S p 5 C$ spinal trigeminal nucleus, caudal part; $\mathrm{Sp} 5 \mathrm{Cl}$ spinal trigeminal nucleus, caudal part, lamina 1; Sp5C2 spinal trigeminal nucleus, caudal part, lamina 2; Sp5C3/4 spinal trigeminal nucleus, caudal part, lamina $3 / 4$. Scale bar $\mathbf{A}, \mathbf{B}=\mathbf{C}=1 \mathrm{~mm} ; \mathbf{D}$, $\mathbf{E}=\mathbf{F}=1 \mathrm{~mm}$ 

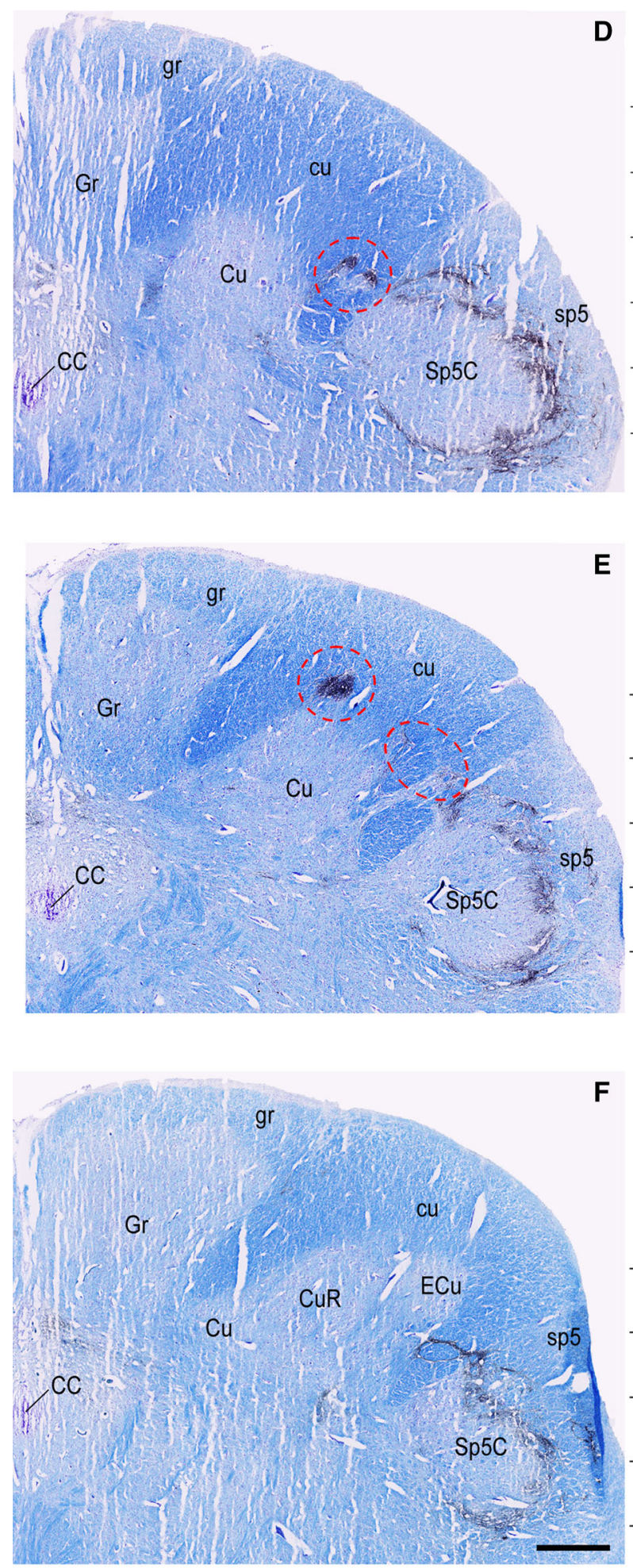

Fig. 9 continued

agreement with the well-established notion of trigeminal primary afferent input to the $\mathrm{Cu}$ (see Murfert and Rajchert 1991 and references therein). In keeping with such a
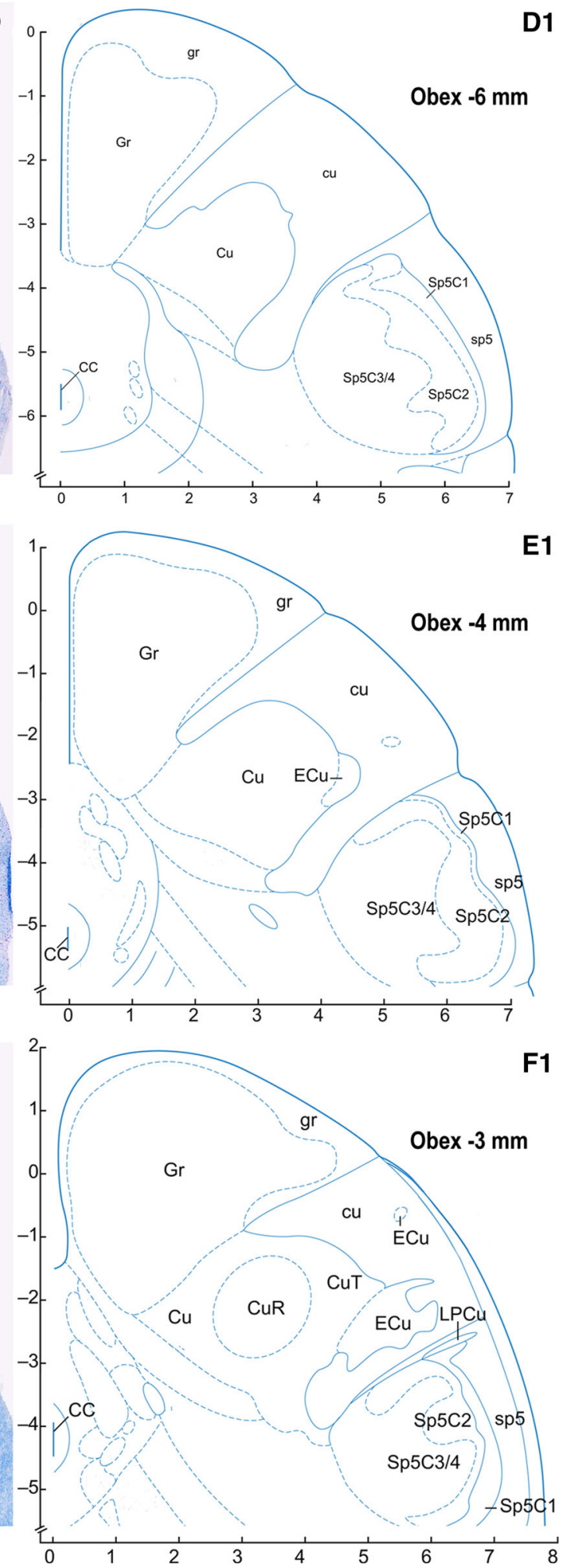

D1

E1

F1

composition of the white matter is the fact that nociceptive responses have been recorded in the dorsal column nuclei (Ferrington et al. 1988; Cliffer et al. 1992; Usunoff et al. 
2006; Zhao et al. 2011). Moreover, the dorsal column pathway appears to be involved in chronic neuropathic pain states (Ossipov et al. 2000). Of particular interest is the postsynaptic dorsal column (PSDC) pathway, a fiber system originating from spinal cord cells postsynaptic to primary afferent fibers (Rustioni 1976; Giesler et al. 1984; Cliffer and Willis 1994). The PSDC pathway has a major role in visceral nociception (Cliffer and Giesler 1989; Berkley and Hubscher 1995; Hirshberg et al. 1996; Feng et al. 1998; Al-Chaer et al. 1999; Willis et al. 1999; Wang et al. 1999) and its surgical disruption represents a successful strategy in the control of visceral cancer pain in patients (Hirshberg et al. 1996; Nauta et al. 1997; Kim and Kwon 2000; Gildenberg 2001). Experimental findings show that the PSDC pathway contains peptidergic fibers (Conti et al. 1990). Particularly in view of the possible clinical implications, namely the prospect of a pharmacological rather than surgical pain therapy (see Wang et al. 2011), it is important to define accurately the chemistry of this pathway. Based on their neurochemical features, it is tempting to speculate the involvement of the $\mathrm{Cu}$ subregions in the processing of pain stimuli and possibly in visceral nociception. On the other hand, comparative analyses in different species across mammalian Orders indicate that the PSDC pathway, rather than to discrete areas, has a general widespread distribution in the $\mathrm{Cu}$ (Cliffer and Giesler 1989; Cliffer and Willis 1994) and projects to both cuneate and gracile nuclei (Giesler et al. 1984; Palecek et al. 2003a, b). In particular, in the monkey, the PSDC pathway has been show to reach all parts of the $\mathrm{Cu}$, including pars rotunda, and the external $\mathrm{Cu}$ (Cliffer and Willis 1994).

In conclusion, we show that immunoreactivity to a number of molecules with major roles in protopathic neuronal transmission, trophism and plasticity concentrates in restricted areas of the human $\mathrm{Cu}$, mostly located at caudal levels of the nucleus, along its dorsal edge or embedded in the white matter of the cuneate fascicle, and propose that such subregions may represent a distinct subdivision of the human dorsal column nuclei with neurochemical and histological features analogous to those of the protopathic and nociceptive sensory nuclei. Their occurrence in the human $\mathrm{Cu}$ poses numerous questions that demand further investigations. For instance, as among the subdivisions of the dorsal column nuclear complex we could detect them exclusively within the territory of the $\mathrm{Cu}$, whether or not their functional involvement is committed to serve both the upper and lower part of the body remains to be elucidated. Studies should be aimed at clarifying whether or not they are exclusively found in the human brain, since similar clear-cut subregions, endowed with the described neurochemical properties, have not been reported in other species. The possibility may be considered that they may have gone unnoticed. In fact, in their wider extent, they appear concentrated at two longitudinal segments, and a thorough inspection of the medulla oblongata is required to detect them. Crucial would be their identification in experimental animals, and particularly in primates, as studies aimed at clarifying their fine structure, chemistry, hodology and functional implications could then be envisaged.

Conflict of interest The authors declare that they have no conflicts of interest.

Open Access This article is distributed under the terms of the Creative Commons Attribution License which permits any use, distribution, and reproduction in any medium, provided the original author(s) and the source are credited.

\section{References}

Al-Chaer ED, Feng Y, Willis WD (1999) Comparative study of viscerosomatic input onto postsynaptic dorsal column and spinothalamic tract neurons in the primate. J Neurophysiol 82:1876-1882

Anand P, Gibson SJ, Yiangou Y, Christofides ND, Polak JM, Bloom SR (1984) PHI-like immunoreactivity co-locates with the VIPcontaining system in human lumbosacral spinal cord. Neurosci Lett 46:191-196

Benowitz LI, Apostolides PJ, Perrone-Bizzozero N, Finklestein SP, Zwiers H (1988) Anatomical distribution of the growth-associated protein GAP-43/B-50 in the adult rat brain. J Neurosci 8:339-352

Berkley KJ, Hubscher CH (1995) Are there separate central nervous system pathways for touch and pain? Nat Med 1:766-773

Bisby MA (1988) Dependence of GAP43 (B50, Fl) transport on axonal regeneration in rat dorsal root ganglion neurons. Brain Res 458:157-161

Bishop AE, Polak JM, Yangou Y, Christofides ND, Bloom SR (1984) The distribution of PHI and VIP in porcine gut and their colocalization to a proportion of intrinsic ganglion cells. Peptides 5:255-259

Blomqvist A, Broman J (1993) Serotoninergic innervation of the dorsal column nuclei and its relation to cytoarchitectonic subdivisions: an immunohistochemical study in cats and monkeys (Aotus trivirgatus). J Comp Neurol 327:584-596

Bonfanti L, Olive S, Poulain DA, Theodosis DT (1992) Mapping of the distribution of polysialylated neural cell adhesion molecule throughout the central nervous system of the adult rat: an immunohistochemical study. Neuroscience 49:419-436

Briner RP, Carlton SM, Coggeshall RE, Chung KS (1988) Evidence for unmyelinated sensory fibres in the posterior columns in man. Brain 111:999-1007

Broman J (1994) Neurotransmitters in subcortical somatosensory pathways. Anat Embryol 189:181-214

Chigr F, Najimi M, Leduque P, Charnay Y, Jordan D, Chayvialle JA, Tohyama M, Kopp N (1989) Anatomical distribution of somatostatin immunoreactivity in the infant brainstem. Neuroscience 29:615-628

Chung KS, Coggeshall RE (1985) Unmyelinated primary afferent fibers in dorsal funiculi of cat sacral spinal cord. J Comp Neurol 238:365-369

Chung K, Langford LA, Coggeshall RE (1987) Primary afferent and propriospinal fibers in the rat dorsal and dorsolateral funiculi. J Comp Neurol 263:68-75 
Chung K, Briner RP, Carlton SM, Westlund KN (1989) Immunohistochemical localization of seven different peptides in the human spinal cord. J Comp Neurol 280:158-170

Cliffer KD, Giesler GJ Jr (1989) Postsynaptic dorsal column pathway of the rat. III. Distribution of ascending afferent fibers. J Neurosci 9:3146-3168

Cliffer KD, Willis WD (1994) Distribution of the postsynaptic dorsal column projection in the cuneate nucleus of monkeys. J Comp Neurol 345:84-93

Cliffer KD, Hasegawa T, Willis WD (1992) Responses of neurons in the gracile nucleus of cats to innocuous and noxious stimuli: basic characterization and antidromic activation from the thalamus. J Neurophysiol 68:818-832

Conrath-Verrier M, Dietl M, Arluison M, Cesselin F, Bourgoin S, Hamon M (1983) Localization of Met-enkephalin-like immunoreactivity within pain-related nuclei of cervical spinal cord, brainstem and midbrain in the cat. Brain Res Bull 11:587-604

Conti F, De Biasi S, Giuffrida R, Rustioni A (1990) Substance P containing projections in the dorsal columns of rats and cats. Neuroscience 34:607-621

Coons AH, Kaplan MH (1950) Localization of antigen in tissue cells; improvements in a method for the detection of antigen by means of fluorescent antibody. J Exp Med 91:1-13

Cuello AC, Kanazawa I (1978) The distribution of substance P immunoreactive fibers in the rat central nervous system. J Comp Neurol 178:129-156

Cuello AC, Polak JM, Pearse AGE (1976) Substance P: a naturally occurring transmitter in human spinal cord. Lancet 2:1054-1056

Cuello AC, Galfre G, Milstein C (1979) Detection of substance P in the central nervous system by a monoclonal antibody. Proc Natl Acad Sci USA 76:3532-3536

Dalsgaard CJ, Jonsson CE, Hökfelt T, Cuello AC (1983) Localization of substance P-immunoreactive nerve fibers in the human digital skin. Experientia 39:1018-1020

De Biasi S, Rustioni A (1990) Ultrastructural immunocytochemical localization of excitatory amino acids in the somatosensory system. J Histochem Cytochem 38:1745-1754

De Biasi S, Vitellaro-Zuccarello L, Bernardi P, Valtschanoff JG, Weinberg RJ (1994) Ultrastructural and immunocytochemical characterization of primary afferent terminals in the rat cuneate nucleus. J Comp Neurol 347:275-287

De Koninck Y, Ribeiro-da-Silva A, Henry JL, Cuello AC (1992) Spinal neurons exhibiting a specific nociceptive response receive abundant substance P-containing synaptic contacts. Proc Natl Acad Sci USA 89:5073-5077

De Lanerolle NC, LaMotte CC (1982) The human spinal cord: substance $\mathrm{P}$ and methionine-enkephalin immunoreactivity. J Neurosci 2:1369-1386

Del Fiacco M, Quartu M (1994) Somatostatin, galanin and peptide histidine isoleucine in the newborn and adult human trigeminal ganglion and spinal nucleus: immunohistochemistry, neuronal morphometry and colocalization with substance P. J Chem Neuroanat 7:171-184

Del Fiacco M, Dessi ML, Atzori MG, Levanti MC (1983) Substance $\mathrm{P}$ in the human brainstem. Preliminary results of its immunohistochemical localization. Brain Res 264:142-147

Del Fiacco M, Dessì ML, Levanti MC (1984) Topographical localization of substance $\mathrm{P}$ in the human post-mortem brainstem. An immunohistochemical study in the newborn and adult tissue. Neuroscience 12:591-611

Del Fiacco M, Quartu M, Priestley JV, Setzu MD, Lai ML (1994) GAP-43 persists in adulthood and coexists with SP and CGRP in human trigeminal sensory neurones. Neuroreport 5:2349-2352

Del Fiacco M, Quartu M, Serra MP, Follesa P, Lai ML, Bachis A (2002) Topographical localization of glial cell line-derived neurotrophic factor in the human brain stem: an immunohistochemical study of prenatal, neonatal and adult brains. J Chem Neuroanat 23:29-48 (erratum in: J Chem Neuroanat (2002) 23:299-304)

Fabri M, Conti F (1990) Calcitonin gene-related peptide-positive neurons and fibers in the cat dorsal column nuclei. Neuroscience $35: 167-174$

Feng Y, Cui M, Al-Chaer ED, Willis WD (1998) Epigastric antinociception by cervical dorsal column lesions in rats. Anesthesiology 89:411-420

Ferrington DG, Downie JW, Willis WD Jr (1988) Primate nucleus gracilis neurons: responses to innocuous and noxious stimuli. J Neurophysiol 59:886-907

Galindo A, Krnjević K, Schwartz S (1967) Micro-iontophoretic studies on neurones in the cuneate nucleus. J Physiol 192:359-377

Giesler GJ Jr, Nahin RL, Madsen AM (1984) Postsynaptic dorsal column pathway of the rat. I. Anatomical studies. J Neurophysiol 51:260-275

Gildenberg PL (2001) Myelotomy through the years. Stereotact Funct Neurosurg 77:169-171

Haber S, Elde R (1982) The distribution of enkephalin immunoreactive fibers and terminals in the monkey central nervous system: an immunohistochemical study. Neuroscience 7:1049-1095

Heino R, Westman J (1991) Quantitative analysis of the feline dorsal column nuclei and their GABAergic and non-GABAergic neurons. Anat Embryol 184:181-193

Henderson Z, Sherriff FE (1991) Distribution of choline acetyltransferase immunoreactive axons and terminals in the rat and ferret brainstem. J Comp Neurol 314:147-163

Hirshberg RM, Al-Chaer ED, Lawand NB, Westlund KN, Willis WD (1996) Is there a pathway in the posterior funiculus that signals visceral pain? Pain 67:291-305

Hoeflinger BF, Bennett-Clarke CA, Chiaia NL, Killackey HP, Wall JT, Rhoades RW (1993) Lesion-induced changes in the central terminal distribution of galanin-immunoreactive axons in the dorsal column nuclei. J Comp Neurol 332:378-389

Hökfelt T, Ljungdahl A, Terenius L, Elde R, Nilsson G (1977) Immunohistochemical analysis of peptide pathways possibly related to pain and analgesia: enkephalin and substance P. Proc Natl Acad Sci USA 74:3081-3085

Holstege JC, Jongen JL, Kennis JH, van Rooyen-Boot AA, Vecht CJ (1998) Immunocytochemical localization of GDNF in primary afferents of the lumbar dorsal horn. Neuroreport 9:2893-2897

Ide K, Yasumasa S, Hiromoto I, Hironubu I (1996) Sensory nerve supply in the human subacromial bursa. J Should Elb Surg 5:371-382

Ishida-Yamamoto A, Senba E, Tohyama M (1988) Calcitonin generelated peptide- and substance P-immunoreactive nerve fibers in Meissner's corpuscles of rats: an immunohistochemical analysis. Brain Res 453:362-366

Jain N, Florence SL, Kaas JH (1995) GAP-43 expression in the medulla of macaque monkeys: changes during postnatal development and the effects of early median nerve repair. Brain Res Dev Brain Res 90:24-34

Johansson O, Hökfelt T, Elde RP (1984) Immunohistochemical distribution of somatostatin-like immunoreactivity in the central nervous system of the adult rat. Neuroscience 13:265-339

Jongen JL, Dalm E, Vecht CJ, Holstege JC (1999) Depletion of GDNF from primary afferents in adult rat dorsal horn following peripheral axotomy. Neuroreport 10:867-871

Kawamoto Y, Nakamura S, Matsuo A, Akiguchi I, Shibasaki H (2000) Immunohistochemical localization of glial cell linederived neurotrophic factor in the human central nervous system. Neuroscience 100:701-712

Kim YS, Kwon SJ (2000) High thoracic midline dorsal column myelotomy for severe visceral pain due to advanced stomach cancer. Neurosurgery 46:85-90 
Kitagawa J, Tsuboi Y, Ogawa A, Ren K, Hitomi S, Saitoh K, Takahashi O, Masuda Y, Harada T, Hanzawa N, Kanda K, Iwata $\mathrm{K}$ (2005) Involvement of dorsal column nucleus neurons in nociceptive transmission in aged rats. J Neurophysiol 94:4178-4187

Kordower JH, Le HK, Mufson EJ (1992) Galanin immunoreactivity in the primate central nervous system. J Comp Neurol 319:479-500

Koutcherov Y, Halliday G, Paxinos G, Huang X-F (2004) Organization of human brain stem nuclei. In: Paxinos G, Mai JK (eds) The human nervous system, 2nd edn. Elsevier Academic Press, San Diego, pp 267-320

Langford LA, Coggeshall RE (1981) Unmyelinated axons in the posterior funiculi. Science 211:176-177

Ljungdahl A, Hökfelt T, Nilsson G (1978) Distribution of substance P-like immunoreactivity in the central nervous system of the rat-I. Cell bodies and nerve terminals. Neuroscience 3:861-943

Lue JH, Chen SH, Shieh JY, Wen CY (2001) Afferent synaptic contacts on glycine-immunoreactive neurons in the rat cuneate nucleus. Synapse 41:139-149

Ma W, Bisby MA (1997) Differential expression of galanin immunoreactivities in the primary sensory neurons following partial and complete sciatic nerve injuries. Neuroscience 79:1183-1195

Maqbool A, Batten TF, Berry PA, McWilliam PN (1993) Distribution of dopamine-containing neurons and fibres in the feline medulla oblongata: a comparative study using catecholamine-synthesizing enzyme and dopamine immunohistochemistry. Neuroscience 53:717-733

Marfurt CF, Rajchert DM (1991) Trigeminal primary afferent projections to "non-trigeminal" areas of the rat central nervous system. J Comp Neurol 303:489-511

McNeill DL, Chung K, Carlton SM, Coggeshall RE (1988) Calcitonin gene-related peptide immunostained axons provide evidence for fine primary afferent fibers in the dorsal and dorsolateral funiculi of the rat spinal cord. J Comp Neurol 272:303-308

Melander T, Hökfelt T, Rökaeus A (1986) Distribution of galaninlike immunoreactivity in the rat central nervous system. J Comp Neurol 248:475-517

Michael GJ, Averill S, Nitkunan A, Rattray M, Bennett DL, Yan Q, Priestley JV (1997) Nerve growth factor treatment increases brain-derived neurotrophic factor selectively in TrkA-expressing dorsal root ganglion cells and in their central terminations within the spinal cord. J Neurosci 17:8476-8490

Miki K, Fukuoka T, Tokunaga A, Noguchi K (1998) Calcitonin generelated peptide increase in the rat spinal dorsal horn and dorsal column nucleus following peripheral nerve injury: up-regulation in a subpopulation of primary afferent sensory neurons. Neuroscience 82:1243-1252

Nacimiento W, Töpper R, Fischer A, Oestreicher AB, Nacimiento AC, Gispen WH, Noth J, Kreutzberg GW (1993) Immunocytochemistry of B-50 (GAP-43) in the spinal cord and in dorsal root ganglia of the adult cat. J Neurocytol 22:413-424

Nauta HJ, Hewitt E, Westlund KN, Willis WD Jr (1997) Surgical interruption of a midline dorsal column visceral pain pathway. Case report and review of the literature. J Neurosurg 86:538-542

Noguchi K, Kawai Y, Fukuoka T, Senba E, Miki K (1995) Substance $\mathrm{P}$ induced by peripheral nerve injury in primary afferent sensory neurons and its effect on dorsal column nucleus neurons. J Neurosci 15:7633-7643

Ossipov MH, Lai J, Malan TP Jr, Porreca F (2000) Spinal and supraspinal mechanisms of neuropathic pain. Ann N Y Acad Sci 909:12-24

Palecek J, Paleckova V, Willis WD (2003a) Fos expression in spinothalamic and postsynaptic dorsal column neurons following noxious visceral and cutaneous stimuli. Pain 104:249-257
Palecek J, Paleckova V, Willis WD (2003b) Postsynaptic dorsal column neurons express NK1 receptors following colon inflammation. Neuroscience 116:565-572

Patterson JT, Coggeshall RE, Lee WT, Chung K (1990) Long ascending unmyelinated primary afferent axons in the rat dorsal column: immunohistochemical localizations. Neurosci Lett 108:6-10

Paxinos G, Huang XF (1995) Atlas of the human brainstem. Academic Press, San Diego

Paxinos G, Törk I, Halliday G, Mehler WR (1990) Human homologs to brainstem nuclei identified in other animals as revealed by acetylcholinesterase activity. In: Paxinos G (ed) The human nervous system, 1st edn. Academic Press, San Diego, pp 149-202

Paxinos G, Huang X, Sengul G, Watson C (2012) Organization of brainstem nuclei. In: Mai JK, Paxinos G (eds) The human nervous system, 3rd edn. Elsevier Academic Press, Amsterdam, pp 260-327

Pearson J, Brandeis L, Cuello AC (1982) Depletion of substance P-containing axons in substantia gelatinosa of patients with diminished pain sensitivity. Nature 295:61-63

Pioro EK, Hughes JT, Cuello AG (1984) Demonstration of substance $\mathrm{P}$ immunoreactivity in the nucleus dorsalis of human spinal cord. Neurosci Lett 51:61-65

Popratiloff A, Valtschanoff JG, Rustioni A, Weinberg RJ (1996) Colocalization of GABA and glycine in the rat dorsal column nuclei. Brain Res 706:308-312

Probert L, De Mey J, Polak JM (1983) Ultrastructural localization of four different neuropeptides within separate populations of p-type nerves in the guinea pig colon. Gastroenterology 85:1094-1104

Quartu M, Del Fiacco M (1994) Enkephalins occur and colocalize with substance $\mathrm{P}$ in human trigeminal ganglion neurones. Neuroreport 5:465-468

Quartu M, Diaz G, Floris A, Lai ML, Priestley JV, Del Fiacco M (1992) Calcitonin gene-related peptide in the human trigeminal sensory system at developmental and adult life stages: immunohistochemistry, neuronal morphometry and coexistence with substance P. J Chem Neuroanat 5:143-157

Quartu M, Lai ML, Del Fiacco M (1995) GAP-43 in the spinal trigeminal and dorsal column nuclei of the newborn and adult man: immunohistochemical distribution and comparison with that of the neuropeptides SP and CGRP. Ital J Anat Embryol 100 S1:205-211

Quartu M, Serra MP, Bachis A, Lai ML, Ambu R, Del Fiacco M (1999) Glial cell line-derived neurotrophic factor-like immunoreactivity in human trigeminal ganglion and nucleus. Brain Res 847:196-202

Quartu M, Serra MP, Boi M, Ferretti MT, Lai ML, Del Fiacco M (2007a) Tissue distribution of Ret, GFRalpha-1, GFRalpha-2 and GFRalpha-3 receptors in the human brainstem at fetal, neonatal and adult age. Brain Res 1173:36-52

Quartu M, Serra MP, Boi M, Sestu N, Lai ML, Del Fiacco M (2007b) Tissue distribution of neurturin, persephin and artemin in the human brainstem at fetal, neonatal and adult age. Brain Res 1143:102-115

Quartu M, Serra MP, Boi M, Ibba V, Melis T, Del Fiacco M (2008) Polysialylated-neural cell adhesion molecule (PSA-NCAM) in the human trigeminal ganglion and brainstem at prenatal and adult ages. BMC Neurosci 9:108. doi:10.1186/1471-2202-9108

Rikard-Bell GC, Törk I, Sullivan C, Scheibner T (1990) Distribution of substance P-like immunoreactive fibres and terminals in the medulla oblongata of the human infant. Neuroscience 34:133-148 
Roberts PJ (1974) The release of amino acids with proposed neurotransmitter function from the cuneate and gracile nuclei of the rat in vivo. Brain Res 67:419-428

Rustioni A (1976) Spinal neurons project to the dorsal column nuclei of rhesus monkeys. Science 196(4290):656-658

Rustioni A, Weinberg RJ (1989) The somatosensory system. In: Björklund A, Hökfelt T, Swanson LW (eds) Handbook of chemical neuroanatomy, Vol 7. Integrated systems of the CNS, part II. Elsevier Science Publishers B.V. (Biomedical Division), Amsterdam, pp 219-321

Rustioni A, Schmechel DE, Cheema S, Fitzpatrick D (1984) Glutamic acid decarboxylase-containing neurons in the dorsal column nuclei of the cat. Somatosens Res 1:329-357

Schoenen J, Faull RLM (2004) Spinal cord: cyto- and chemoarchitecture. In: Paxinos G, Mai JK (eds) The human nervous system, 2nd edn. Elsevier Academic Press, San Diego, pp 190-232

Schreyer DJ, Skene JH (1991) Fate of GAP-43 in ascending spinal axons of DRG neurons after peripheral nerve injury: delayed accumulation and correlation with regenerative potential. J Neurosci 11:3738-3751

Seki T, Arai Y (1993) Distribution and possible roles of the highly polysialylated neural cell adhesion molecule (NCAM-H) in the developing and adult central nervous system. Neurosci Res 17:265-290

Simantov R, Kuhar MJ, Uhl GR, Snyder SH (1977) Opioid peptide enkephalin: immunohistochemical mapping in rat central nervous system. Proc Natl Acad Sci USA 74:2167-2171

Skene JHP (1984) Growth-associated proteins and the curious dichotomies of nerve regeneration. Cell 37:697-700

Skofitsch G, Jacobowitz DM (1985a) Immunohistochemical mapping of galanin-like neurons in the rat central nervous system. Peptides 6:509-546

Skofitsch G, Jacobowitz DM (1985b) Calcitonin gene-related peptide: detailed immunohistochemical distribution in the central nervous system. Peptides 6:721-745

Taber-Pierce E, Lichentenstein E, Feldman SC (1985) The somatostatin systems of the guinea-pig brainstem. Neuroscience 15:215-235

Tamatani M, Senba E, Tohyama M (1989) Calcitonin gene-related peptide- and substance P-containing primary afferent fibers in the dorsal column of the rat. Brain Res 495:122-130

Tang S, Machaalani R, Waters KA (2010) Immunolocalization of proand mature-brain derived neurotrophic factor (BDNF) and receptor TrkB in the human brainstem and hippocampus. Brain Res 1354:1-14

Tetzlaff W, Zwiers H, Lederis K, Cassar L, Bisby MA (1989) Axonal transport and localization of B50 GAP43-like immunoreactivity in regenerating sciatic and facial nerves of the rat. $\mathrm{J}$ Neurosci 9:1303-1313

Unger JW, Lange W (1991) Immunohistochemical mapping of neurophysins and calcitonin gene-related peptide in the human brainstem and cervical spinal cord. J Chem Neuroanat 4:299-309

Usunoff KG, Popratiloff A, Schmitt O, Wree A (2006) Functional neuroanatomy of pain. Adv Anat Embryol Cell Biol 184:1-115

van Rossum D, Hanisch UK, Quirion R (1997) Neuroanatomical localization, pharmacological characterization and functions of CGRP, related peptides and their receptors. Neurosci Biobehav Rev 21:649-678
Vincent SR, McIntosh CH, Buchan AM, Brown JC (1985) Central somatostatin systems revealed with monoclonal antibodies. J Comp Neurol 238:169-186

Wang CC, Willis WD, Westlund KN (1999) Ascending projections from the area around the spinal cord central canal: a Phaseolus vulgaris leucoagglutinin study in rats. J Comp Neurol 415:341-367

Wang Y, Mu X, Liu Y, Zhang X, Wu A, Yue Y (2011) NK-1receptor-mediated lesion of spinal post-synaptic dorsal column neurons might improve intractable visceral pain of cancer origin. Med Hypotheses 76:102-104

Westman J (1989a) Light and electron microscopical studies of the substance $\mathrm{P}$ innervation of the dorsal column nuclei and the lateral cervical nucleus in the primate. Ups $\mathrm{J}$ Med Sci 94:123-128

Westman J (1989b) Light and electron microscopical studies of the GABA innervation of the dorsal column nuclei and the lateral cervical nucleus in the primate species Macaca fascicularis and Papio anubis. Ups J Med Sci 94:255-270

Wharton J, Polak JM, Pearse AG, McGregor GP, Bryant MG, Bloom SR, Emson PC, Bisgard GE, Will JA (1980) Enkephalin-, VIPand substance P-like immunoreactivity in the carotid body. Nature 284:269-271

Wiese UH, Emson PC, Sheppard RC (1991) Production and characterization of an anti-peptide antibody specific for the growth-associated protein, GAP-43. Brain Res 554:145-152

Willis WD, Al-Chaer ED, Quast MJ, Westlund KN (1999) A visceral pain pathway in the dorsal column of the spinal cord. Proc Natl Acad Sci USA 96:7675-7679

Woolf CJ, Reynolds ML, Molander C, O'Brien C, Lindsay RM, Benowitz LI (1990) The growth-associated protein GAP-43 appears in dorsal root ganglion cells and in the dorsal horn of the rat spinal cord following peripheral nerve injury. Neuroscience 34:465-478

Yan Q, Rosenfeld RD, Matheson CR, Hawkins N, Lopez OT, Bennett L, Welcher AA (1997) Expression of Brain-derived neurotrophic factor protein in the adult rat central nervous system. Neuroscience 78:431-448

Yeh JH, Lue JH, Wang HY, Huang CT, Tsai YJ (2008) Synaptic relationships between induced neuropeptide Y-like immunoreactive terminals and cuneothalamic projection neurons in the rat cuneate nucleus following median nerve transection. J Chem Neuroanat 36:27-32. doi:10.1016/j.jchemneu.2008.05.006

Zhang X, Meister B, Elde R, Verge VM, Hökfelt T (1993) Large calibre primary afferent neurons projecting to the gracile nucleus express neuropeptide $\mathrm{Y}$ after sciatic nerve lesions: an immunohistochemical and in situ hybridization study in rats. Eur $\mathrm{J}$ Neurosci 5:1510-1519

Zhao F, Welsh D, Williams M, Coimbra A, Urban MO, Hargreaves R, Evelhoch J, Williams DS (2011) fMRI of pain processing in the brain: a within-animal comparative study of BOLD vs. CBV and noxious electrical vs. noxious mechanical stimulation in rat. Neuroimage. doi:10.1016/j.neuroimage.2011.08.002

Zou XC, Martin GF (1995) The distribution of GAP-43 immunoreactivity in the central nervous system of adult opossums (Didelphis virginiana) with notes on their development. Brain Behav Evol 45:63-83 